\title{
POTENTIAL POLLEN VECTORS OF THE MASS FLOWERING TREE ACACIA DEALBATA, WITHIN ITS NATURAL RANGE IN SOUTHERN TASMANIA
}

\author{
by A. Rod Griffin, Andrew B. Hingston, Christopher E. Harwood, Jane L. Harbard, Michael J. Brown, \\ Kristi M. Ellingsen and Catherine M. Young
}

(with three figures, three plates, six tables and two appendices)

Griffin, A.R., Hingston, A.B., Harwood, C.E., Harbard, J.L., Brown, M.J., Ellingsen, K.M. \& Young, C.M. 2020 (9:xii): Potential
pollen vectors of the mass flowering tree Acacia dealbata, within its natural range in southern Tasmania. Papers and Proceedings of
the Royal Society of Tasmania 154: 9-26. https://doi.org/10.26749/rstpp.154.9 ISSN 0080-4703. Discipline of Biological
Sciences, University of Tasmania, Private Bag 55, Hobart, Tasmania 7001, Australia (RG*, CEH, JLH, CMY); Discipline of
Geography and Spatial Sciences, University of Tasmania, Private Bag 78, Hobart, Tasmania 7001, Australia (ABH); 211 Channel
Highway, Taroona, Tasmania 7006, Australia (MJB); 16 Auvergne Avenue, Mount Stuart, Tasmania 7000, Australia (KME).
*Author for correspondence: Email: rodgriffin@iinet.net.au

In Tasmania, Acacia dealbata flowers from July to September when weather conditions are non-conducive to activity by the insects which are generally considered to be major pollinators of the genus. This paper examines the presence and behaviour of insect and bird visitors as potential pollen vectors. Very few insects were observed to visit the flowers. However, several bird species fed on the flower-heads and foraged for small invertebrates inhabiting the blossoms. These feeding behaviours resulted in adhesion of pollen to feathers likely to be transferred from one genet to another as birds moved. During feeding, rosellas were observed to not only ingest flower-heads but the presence of branchlet clip under $57 \%$ of $A$. dealbata trees surveyed is evidence of the widespread occurrence of these species foraging on flowers. However, given the profusion of flowers and the small numbers of birds observed, it is difficult to conclude that birds are wholly responsible for outcross pollination and we discuss the possibility that wind may also be an important pollen vector. Although the floral attributes of $A$. dealbata are more aligned with insect pollination, we failed to definitively identify any one major pollinator of the species in this environment and suggest that the pollination syndrome may most accurately be described as generalist.

Key Words: Acacia dealbata, pollination syndrome, bird pollination, insect pollination, wind pollination, mass flowering.

\section{INTRODUCTION}

Silver Wattle (Acacia dealbata) is native to southeastern Australia with a range extending from Tasmania and western Victoria to northern New South Wales. It is common in forest and woodland communities in Tasmania from sea level to $900 \mathrm{~m}$, and dominates many transitional forests on disturbed sites (Kitchener \& Harris 2013), varying in size from a low shrub on dry sites to a tall tree over $25 \mathrm{~m}$ in height on deep soils in wetter sites (Boland et al. 2006). The species has also been widely planted outside Australia for ornamental purposes, perfumery and fuelwood (Griffin et al. 2011) and has a reputation for weediness via both seed and root suckering (Gibson et al. 2011, Fuentes-Ramirez et al. 2011, Montesinos et al. 2016). Because of the tendency to sucker (Nghiem et al. 2018), pollen transfer between trees is not always an outcrossing event and we use the term 'genet' to indicate trees of different genotype.

The species produces a spectacular display of bright yellow flowers from July to September, a time of year characterised by low temperatures with frequent strong winds and rain, not conducive to insect flight activity. However, substantial pollen transfer between genets is presumed to occur as Broadhurst et al. (2008) found that seed from elsewhere within the natural range was highly outcrossed. The vector(s) mediating such cross-pollination in Tasmanian populations are by no means obvious.

According to the pollination syndrome hypothesis, convergent evolution may lead to unrelated plants sharing the same suite of floral traits when they are pollinated by the same abiotic or functional group of biotic vectors (Faegri \& van der Pijl 1979, Rosas-Guerrero et al. 2014). For biotic pollinators, floral traits include rewarding (e.g. nectar and pollen) and non-rewarding attractants (e.g. floral colour, shape and scent), while the wind-pollination syndrome is typically associated with an absence of attractants, the flowers being nectarless and lacking bright colours and scent (Faegri \& van der Pijl 1979, Sedgley \& Griffin 1989).

Acacia species are generally considered to be pollinated by insects, particularly bees (Bernhardt 1989, Stone et al. 2003), but the floral traits do not map tightly onto any of the major pollinator syndromes as defined by Faegri and van der Pijl (1979). In terms of gross morphology, the flowers are remarkably uniform, a characteristic feature being the prominence of anther filaments which generally determine the shape, size and (generally yellow) colour of the flower-heads, which may be globose to spicate (Kendrick 2003). The number of individual flowers per head and heads per inflorescence are variable and all may not be perfect. Pollen is aggregated into polyads containing $4<32$ grains. The flowers do not produce nectar and while extrafloral nectaries are generally present (Boughton 1981), in many species, including $A$.dealbata, they are only vestigial (Marazzi et al. 2019) and offer no reward to visitors. Low reproductive success is also a characteristic of the genus with typically less than one pod produced per flower-head (Wandrag et al. 2015). Nevertheless, because of the large number of flowers per tree, individuals may produce several 
thousand seeds $/ \mathrm{m}^{2} / \mathrm{yr}^{-1}$ (Gibson et al. 2011) which can remain viable in the soil for many decades.

Although birds are not considered to be major pollinators of Acacia (Ford et al. 1979), there are examples of birds feeding on or within flowering crowns of several species (Sargent 1928, Ford \& Forde 1976, Knox et al. 1985, Vanstone \& Paton 1988), raising the possibility of a role as pollen vectors. The possibility of wind pollination was not considered in earlier reviews of the pollination ecology of the genus (Bernhardt 1989, Stone et al. 2003) but there is sufficient evidence to suggest at least a contribution to gene flow. Polyads have been collected downwind of A.mearnsii trees (Moncur et al. 1991, Kendrick 2003); Smart and Knox (1979) found Acacia polyads in the atmosphere over Melbourne during spring; and allergy to airborne Acacia pollen has been reported from a number of countries (Ariano et al. 1991). A recent experimental study of $A$. longifolia in Portugal found that seed set was enhanced when flowers were exposed to wind (Giovanetti et al. 2018).

The effectiveness of any particular flower visitor as an outcrossing agent is a function of its morphology and behaviour (affecting the probability of collecting pollen during the course of feeding and of deposition on flowers of a different genet) and of population size relative to the number of flowers produced by the host plant population. Together these variables determine the potential flux of pollen between trees (Griffin et al. 2009). For effective pollination the pollen must obviously be viable when deposited, so it is important to understand the temporal decay in viability post-anthesis. As a contribution to understanding the pollination ecology of A.dealbata, this paper reports an observational study of the presence and behaviour of the diurnal visitors to the crowns of trees in natural populations near Hobart, Tasmania. It also considers the possibility of wind pollination and tentative conclusions are drawn regarding all the relative importance of the potential vectors in effecting outcrossing.

\section{MATERIALS AND METHODS}

\section{Reproductive characteristics of $A$. dealbata}

Flowers are arranged in globose heads which, when the filaments are fully expanded, measure about $9 \mathrm{~mm}$ wide by $8 \mathrm{~mm}$ long with a fresh weight of $20 \mathrm{mg}$ (Griffin unpubl. data). The number of individual flowers per head varies between 22 and 42 (Roger \& Johnson 2013, Correia et al. 2014) with varying numbers being male only. Each flower has an average of 33 stamens (Correia et al. 2014). Heads are arranged in axillary racemes or false panicles on branch apices which collectively form a highly visible mass blossom (Plate 1) and figure 1 in Nghiem et al. (2018). Pollen is aggregated into 16 grain polyads which average $46 \mu \mathrm{m}$ in diameter (Nghiem et al. 2018). The flowers do not produce nectar and the extra-floral nectaries are vestigial (Marazzi et al. 2019) and offer no reward. The low fruit:flower ratio

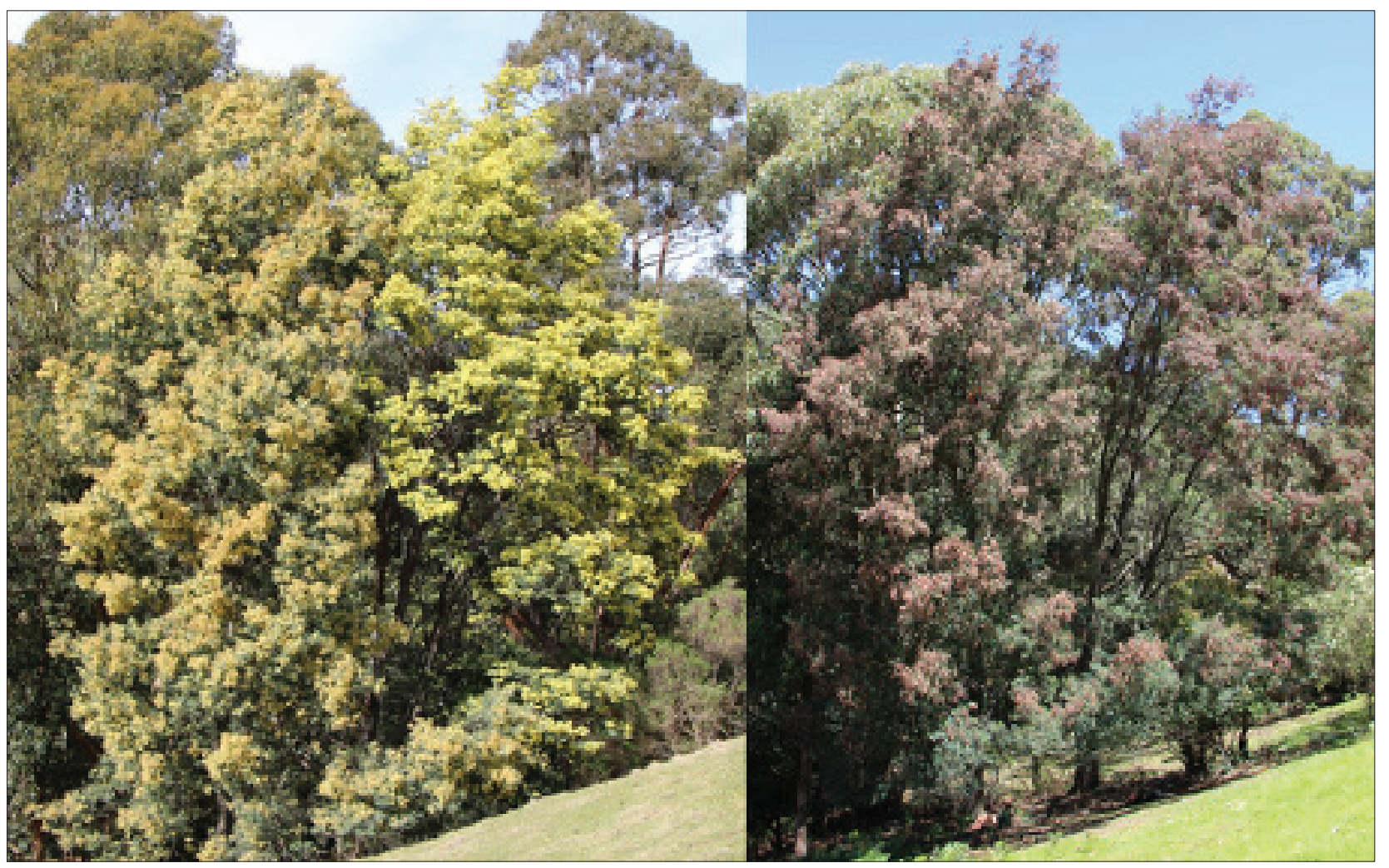

PLATE 1 - Flowering (26/8/18) and corresponding mature pod crop (1/1/19) on adjacent trees at Site 4 . The bright yellow colour of Tree 4 (left) indicates it was in full flower, while Tree 5 (right) was past the peak. Both the flowers and resulting pod crops were distributed uniformly from the topmost branches to the lowest in the crown on each tree (photos J. Harbard). 


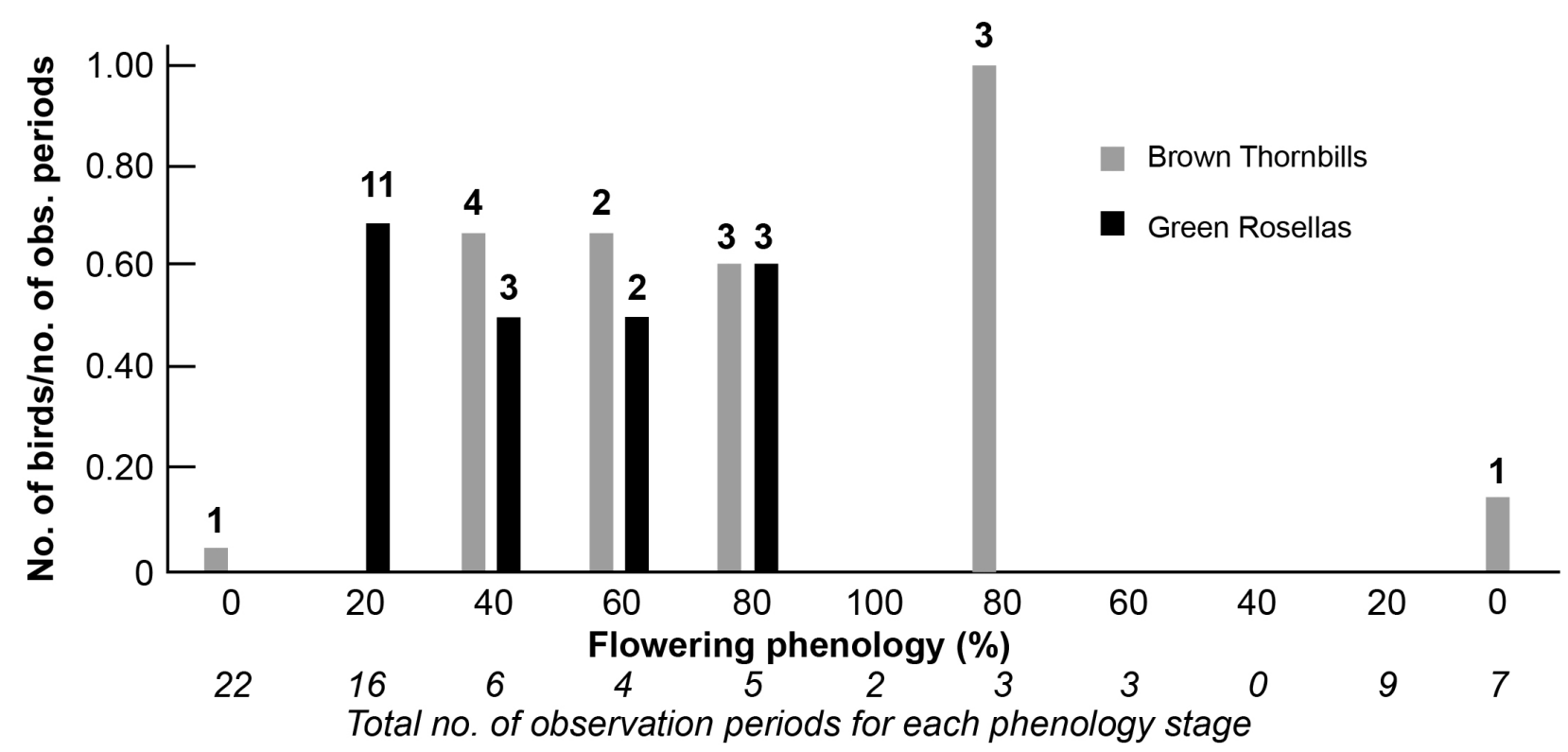

FIG. 1 - Ratios of total number of birds sighted on $A$. dealbata crowns to total number of observation periods at each flowering phenology stage, summed across the five observation points at Knocklofty, for Brown Thornbills and Green Rosellas. Numbers above each bar show the total number of birds sighted for each phenology stage. Flowering phenology scored as the proportion of flowers judged to be fully open on a scale of 0 (pre- and post-flowering) to 5 at peak flowering.

of the species aligns with the rest of the genus. In Portugal, Correia et al. (2014) reported fruit developed from only $0.7 \%$ of the total number of flowers observed. In South Africa, Rodger and Johnson (2013) reported that after open pollination $14 \%$ of $A$. dealbata flower-heads matured one or more fruit while, for a range of natural populations in NSW, infructescences per flower-head varied between $0.03<0.31$ (Broadhurst \& Young 2006, Wandrag et al. 2014).

\section{Observation sites}

The core study was conducted at the Knocklofty Reserve near Hobart (Site 1) but we also report data collected from a number of other sites within the region (table 1). All sites can broadly be regarded as part of a single ecosystem in the foothills of kunanyi/Mount Wellington to the west of Hobart, where $A$. dealbata is present as a result of regeneration following fire or other disturbance, although the density and age class structures differ, with likely effects on the pool of potential pollinations. All are within $15 \mathrm{~km}$ of Site 1 and between $50-300 \mathrm{~m}$ elevation (Site 1 is at $220 \mathrm{~m}$ ).

\section{Floral phenology}

It is highly probable that the state of flower development within a tree crown affects desirability as a food source for visiting animals, so we characterised this for each observation date. In A. dealbata there is a gradual colour change associated with flower opening, from pale to brighter yellow and then paler again past the peak. Each time observations were made,

TABLE 1 - Observation sites

\begin{tabular}{|c|c|c|c|c|c|c|}
\hline $\begin{array}{l}\text { Site } \\
\text { No. }\end{array}$ & Location & Latitude S & Longitude E & $\begin{array}{l}\text { Elevation } \\
(\mathrm{m} \text { asl })\end{array}$ & $\begin{array}{c}\text { Distance } \\
\text { from Site } 1 \\
\qquad(\mathrm{~km})\end{array}$ & Data collected \\
\hline 1 & Knocklofty Reserve & $42^{\circ} 53^{\prime} 07^{\prime \prime}$ & $147^{\circ} 18^{\prime} 07^{\prime \prime}$ & 220 & - & $\begin{array}{l}\text { Bird and invertebrate } \\
\text { observation, mist netting }\end{array}$ \\
\hline 2 & Mt Nelson & $42^{\circ} 54^{\prime} 48^{\prime \prime}$ & $147^{\circ} 19^{\prime} 23^{\prime \prime}$ & 140 & 3.7 & Bird observation \\
\hline 3 & Lower Longley & $42^{\circ} 58^{\prime} 20^{\prime \prime}$ & $147^{\circ} 11^{\prime} 41^{\prime \prime}$ & 200 & 14.5 & Bird observation \\
\hline 4 & Turnip Fields Rd & $42^{\circ} 54^{\prime} 51^{\prime \prime}$ & $147^{\circ} 16^{\prime} 20^{\prime \prime}$ & 300 & 3.6 & $\begin{array}{l}\text { Wind dispersal, seed } \\
\text { production }\end{array}$ \\
\hline 5 & Waterworks Reserve & $42^{\circ} 54^{\prime} 32^{\prime \prime}$ & $147^{\circ} 16^{\prime} 12^{\prime \prime}$ & 160 & 2.4 & Mist netting birds \\
\hline 6 & $\begin{array}{l}\text { BOM Station } 094029 \\
\text { Ellerslie Rd, Hobart }\end{array}$ & $42^{\circ} 53^{\prime} 20^{\prime \prime}$ & $147^{\circ} 19^{\prime} 34^{\prime \prime}$ & 50 & 1.5 & Meteorological data \\
\hline
\end{tabular}


the flowering state of each tree at each Observation Point (OP) was placed in one of 11 categories according to the percentage of heads which were fully open, from $0<100 \%$ (peak flowering) at 20 percentile intervals reducing from this peak date to $0 \%$, again in 20 percentile steps, as the proportion of open heads declined over time. Individual trees thus moved through a progression from $0 \%$ to peak (100\%) flowering and back to $0 \%$. An average score was then calculated for all trees at each bird OP at each study site on each date. For the invertebrate study there was only one target tree at each OP and for results presentation we averaged values over the four trees observed on each visit date.

\section{Meteorological data}

A basic tenet of the study was that the pollination ecology of winter/spring flowering $A$. dealbata may differ from many other Acacia species which flower at warmer times of the year, so we documented the ambient weather conditions through the flowering period using data from the Australian Bureau of Meteorology Station 094029 at Ellerslie Rd, Hobart (table 1) for the study period June-Sept 2018 (Bureau of Meteorology 2018).

\section{Invertebrates visiting or resident within the blossom}

Four trees at Site 1 were chosen for study. The locality, described by Nghiem etal. (2018), is dry sclerophyll eucalypt woodland dominated by Eucalyptus globulus and E. viminalis, with an understorey of $A$. dealbata and other species, but is known to have been more open in the past, with a complex history of degradation and revegetation (Harwood et al. 2018). Each tree was flowering heavily at a height that was easily accessible from the ground. Observations were made on nine days between 30 June 2018 prior to flowering and 18 September, when flowering was completed. Observation days were chosen as being dry and without strong winds, since we expected insect activity to be low under less favourable conditions. For one 10-minute period per tree per observation day we recorded larger flying insects which could be potential pollen vectors. An observer stood close to a heavily flowering part of the crown and noted the number of each taxon which came into view. Where there was some doubt about identification, samples were collected for later examination or in some cases photographed in situ. Where possible, identification was made to the Family level but, with the exception of bees and Syrphid flies, which Bernhardt (1987) considered to be particularly important vectors of Acacia pollen, summary at the level of Order was considered sufficient to meet the study objectives.

We also sampled the small invertebrates living among the inflorescences which represent a potential food source for foraging birds. On each sample day four different flowering branches on each tree were sharply beaten with a $40-\mathrm{cm}$ stick, at an approximate foliage height of $150 \mathrm{~cm}$. A container held immediately below the branches collected the organisms which were dislodged. In order to minimise loss of flying insects the container was fitted with a flexible plastic cover which could be removed and replaced with minimum delay for each of the collections. The pooled contents were then inspected and numbers of each taxon counted. Since a few of the more vigorous flyers (mainly Diptera and Hymenoptera) did escape during the counting process there is some bias associated with the method. However, the more stationary invertebrates are presumed the more likely food for birds, so we do not consider this a critical issue. Where identification was difficult, a digital photographic image was taken for immediate inspection or in some cases later consultation of databases. The camera used was a Canon EOS6D, with Canon MPE65 mm macro lens and Macro twin lite MT-26EX-RT, permitting identifiable images of invertebrates greater than around 2 $\mathrm{mm}$ in length. In order to judge whether the invertebrate fauna was different on flowering and non-flowering trees, on four of the observation days we also beat the foliage of an entirely vegetative tree growing next to Tree 1 . Our capacity to identify the various taxa increased from Species, Genus, Family to Order. For the purposes of this paper we were primarily interested in determining the diversity of organisms over the flowering season and presentation at the level of Order was considered sufficient. More detailed data to Family level are provided in appendix 1, where we also indicate the developmental stage observed, since some taxa were present in a range of immature states (as determined from morphology and/or size) as well as adult form.

\section{Bird visitors}

At Site 1, five fixed OPs were chosen within an area approximately $250 \mathrm{~m}$ by $150 \mathrm{~m}$. Each OP gave an uninterrupted view of 1-5 mature $A$. dealbata trees from a viewing position next to a nearby tree or shrub that provided cover for the observers. Observations were made on 18 days during the period from 26 June (about 2 weeks prior to first anthesis) to 29 September 2018 by which time all flowering had finished. Data were collected by either one or two experienced bird observers with binoculars and cameras. Intervals between the observation days averaged 5.8 days but ranged from 3 to 10 days, depending on the availability of observers and weather conditions.

A second series of observations over the flowering season (26 July to 19 September 2018) was made by another observer at Site 2 (table 1). Ten OPs were selected, seven located within low dry sclerophyll forest with many flowering $A$. dealbata stems $2-8 \mathrm{~m}$ high originating from a past fire event and three in suburban settings near the forest but within $20 \mathrm{~m}$ of buildings that included 1-4 larger $A$. dealbata trees. The number of observations at each OP ranged from 17 to 31 .

A third data set was collected at Site 3 (table 1). Observations were made on a total of ten days between 2 August to 12 October 2018 at a single OP adjacent to a row of five large roadside $A$. dealbata trees on a lightly wooded rural property surrounded by wet sclerophyll forest.

At all sites, observations commenced between 7.30 am to $3 \mathrm{pm}$, with the majority of observations made in the mornings. Periods of the day with very high winds 
(terrestrial Beaufort scale $\geq 7$, large trees in motion) and/ or heavy all-day rain were excluded. Ambient temperatures at the time of observation were mostly within the range $10-15^{\circ} \mathrm{C}$. A point count of ten minutes was made at each OP. During each count, all bird species visible from the OP, or identified from their nearby calls, were recorded. The numbers of birds of each species that alighted on the $A$. dealbata trees under observation, and the numbers that moved between $A$. dealbata trees, were recorded. At Sites 1 and 2 the behaviour of birds in $A$. dealbata tree crowns was noted and each visit recorded as either feeding on inflorescences; contacting flowers; or perching. The frequency of visits by birds that foraged on or among inflorescences of $A$. dealbata in relationship to flowering phenology stages was examined by calculating the proportions of visits to observation periods for each phenological stage.

\section{Indirect evidence of rosella feeding}

It was noted that where Green Rosellas (Platycercus caledonicus) had been feeding on $A$. dealbata flower-heads, the ground under the tree was often littered with freshly clipped flower-bearing branchlets, each severed with a characteristic clean diagonal cut (pl. 2). This provided an indirect measure of activity. To estimate the proportion of trees where this type of feeding had occurred, we inspected the ground under $A$. dealbata trees at nine regional locations where many trees were in heavy flower and there was relatively little undergrowth. Surveyed trees were classified as either plus or minus evidence of rosella feeding (three or more clipped branchlets found under the crown were classified as plus). Results were expressed as percentage of trees with evidence of rosella feeding. It was not possible to judge the time the material had been on the ground and when the feeding had occurred, so we cannot say whether one or more feeding events were involved.

\section{Pollen carried by birds}

For a bird to be an effective outcross pollen vector there must be transfer of polyads from anthers to the bird during the course of a feeding event and from thence to stigmas on another genet. To obtain relevant data we mist-netted bush birds from 7:00 to 11:00 am at Sites 1 and 5 (table 1) while the $A$. dealbata were flowering. Site 5 was first sampled on 22 July, early in the flowering season, with many more trees flowering during the subsequent visit one month later. At Site 1 nets were set near two of the four bird OPs on three occasions at approximately weekly intervals around the peak flowering season in August.

To obtain a pollen swab, doubled-sided tape was applied to a glass microscope slide and, while the bird was still in the mist net (that is before pollen could be rubbed or shaken off), the slide was applied sequentially to the head, beak, feet and chest feathers. Slides were observed through a compound microscope at $400 \times$ magnification, viewing transects across the slide until the whole slide had been observed. Total number of polyads was recorded and classified to at least the Family level.

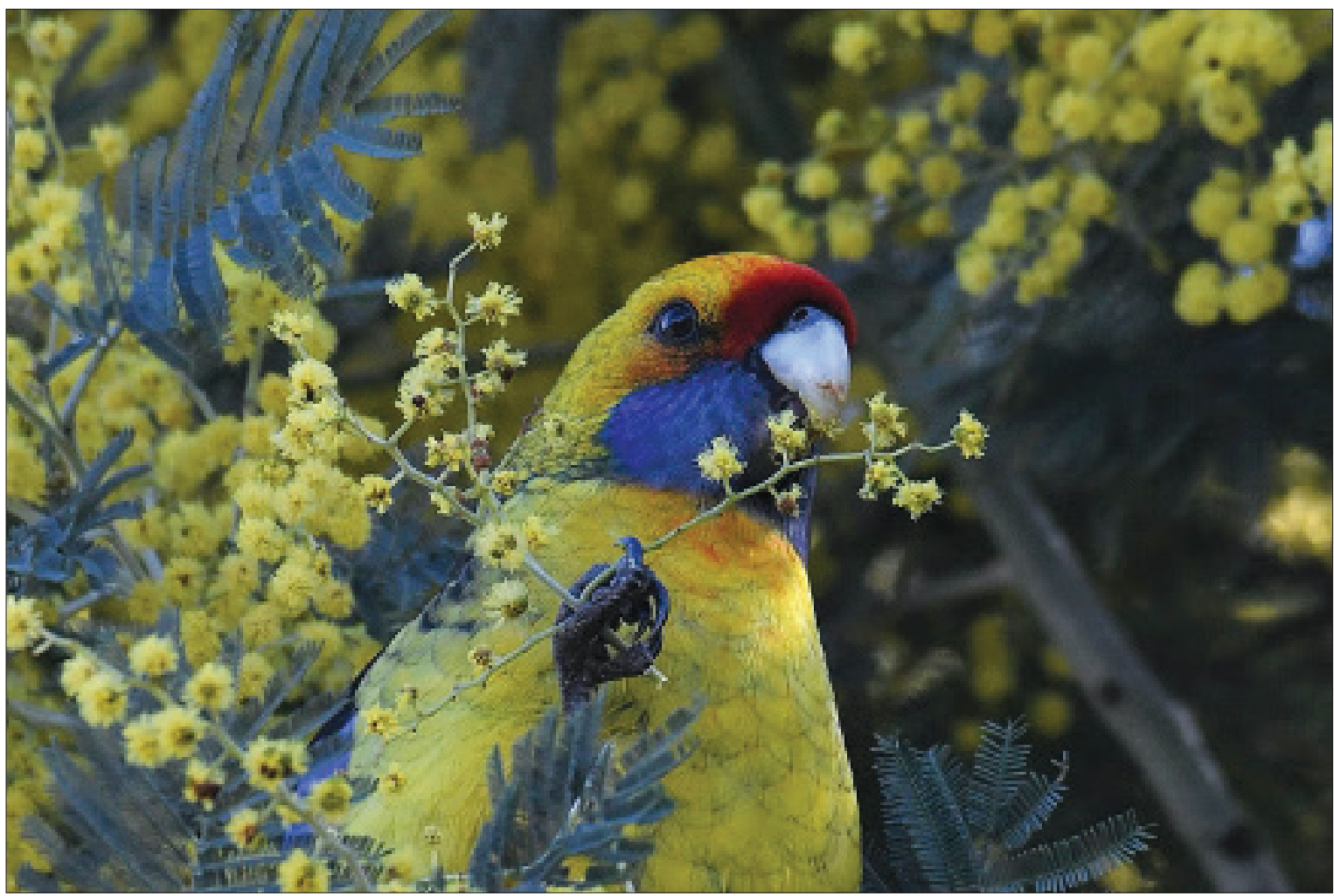

PLATE 2 - Green Rosella feeding on flower-heads from a clipped branchlet of $A$. dealbata (photo M. Brown). 


\section{Pollen viability on feathers}

It was not possible to directly determine viability of pollen carried by birds so we conducted a simulated trial. An equal number of flower-heads was harvested from each of four trees at Site 4 and mixed prior to pollen extraction. Since anthers were closed, the flower-heads were left under lights for 30 minutes causing dehiscence and exposure of the polyads. Flowers were then placed in an Endecotts test sieve with a $63 \mu \mathrm{m}$ stainless steel mesh over a petri dish containing clean feathers from a mist-netted Crescent Honeyeater (Phylidonyris pyrrhopterus). Gentle rubbing separated the polyads from the anthers which settled on the feathers. These were left in a petri dish in an unheated room (temperature range $6-11^{\circ} \mathrm{C}$ ) which was within the range of outside air temperatures over the observation period (Bureau of Meteorology 2018). At intervals between 0 and 17 days, a sample of polyads was collected by gently scraping a dissecting needle over the feathers onto a petri dish containing 1\% agar, 20\% sucrose and $0.01 \%$ boric acid kept at the same ambient temperature. Preliminary experiments determined that maximum germination of fresh polyads was achieved after $48 \mathrm{~h}$ so this was set as the test period. Viability was assessed by viewing pollen tube growth on the nutrient agar at $160 \times$ magnification with an inverted Nikon microscope; 100 polyads were observed on each occasion. A polyad was counted as viable if one or more pollen tubes had germinated and the length was greater than the diameter of the polyad. On Day 3, as germination rate had obviously slowed, the dish was inspected again at $72 \mathrm{~h}$. From Day 7, in order to achieve maximum germination, petri dishes were transferred to a growth room at a higher temperature $\left(15-23^{\circ} \mathrm{C}\right)$.

\section{Wind dispersion of flower-heads}

From casual observation it was evident that whole flowerheads detached rather easily in windy conditions and were frequently seen on the ground among the trees. It is possible to extract viable pollen from such heads (J. Harbard unpubl. data 2018) so this may be regarded as a possible pollen dispersal mechanism. Following a particularly windy week we documented the dispersal of heads away from a forest margin at Site 4. Three parallel transects were laid out across grassland and all heads within a $0.75 \mathrm{~m}^{2}$ wooden frame were counted at $1.5 \mathrm{~m}$ intervals out from below the edge of the canopy to a distance of $50 \mathrm{~m}$. Counts were then converted to a per $1 \mathrm{~m}^{2}$ basis and plotted against distance.

\section{Pod and seed production}

In parallel with this study we have also made a detailed investigation of the floral biology and seed production of this Acacia species. Full details will to be reported elsewhere, but we present some information which, in conjunction with the observed activity of potential pollen vectors, assists inference regarding the overall level of outcross pollination.

If the species is strongly outcrossing and only sets pods after pollination by biotic vectors, we postulate that the pattern of pod set should be patchy because at the visit frequencies we report in this paper it is unlikely, for both stochastic and micro-environmental reasons, that pod set would be even across the whole crown of a tree. We could not quantify such pattern in pod set but we are able to present photographic evidence of trees in full flower and again at pod maturation (pl. 1).

The literature suggests that outcrossed flowers of $A$. dealbata produce a higher number of full seed per pod than selfs (Rodger \& Johnson 2013, Correia et al. 2014), so full seeds per pod may be taken as a rough indication of the level of outcrossing. We determined this trait for pods harvested from the top, middle and bottom of crowns of five trees at Site 4 . These trees ranged in total height from 12-24 m. Two separate samples of pods at each level, ranging in number from 48 to over 500, were dried to open and all seeds extracted and classified as one of four categories: (1) full, black $5 \mathrm{~mm}$; (2) full, brown 5 $\mathrm{mm}$; (3) small, black $3 \mathrm{~mm}$; (4) vestigial, < $2 \mathrm{~mm}$. The total number was counted but only category 1 considered to be good seed. The numbers of total and good seed per pod were then calculated together with the proportion of good seed as a percentage of total seed. The data sets for these three variates were analysed using ANOVA, with tree and height level as the treatment factors in factorial combination.

\section{RESULTS}

The trees at Site 1 flowered over 76 days between 16 July and 29 September with a median date for peak flowering of 24 August The mean number of days that a tree carried some open flowers was 51 and, although there was variation among trees, no genets were fully temporally isolated.

During the flowering period the mean minimum and maximum daily temperatures at the Bureau of Meteorology (Ellerslie Rd site) were $6.4^{\circ} \mathrm{C}$ and $15.1^{\circ} \mathrm{C}$. Mean temperature at 9 am was $9.5^{\circ} \mathrm{C}$ rising to $13.1^{\circ} \mathrm{C}$ at $3 \mathrm{pm}$; at that time mean wind speed was $31 \mathrm{~km} \mathrm{~h}^{-1}$ with a maximum of 71 $\mathrm{km} \mathrm{h}^{-1}$ and a mean relative humidity of $53.5 \%$ (minimum $25 \%$ ). During the flowering season a total of $91.6 \mathrm{~mm}$ of rain fell with $0.2 \mathrm{~mm}$ or more on 41 of the 71 days $(58 \%)$. Weather conditions on bird observation days are noted in appendix 2 together with the respective flowering phenology records.

\section{Invertebrate visitors}

For invertebrates, we documented visits by larger mobile and potentially pollinating insects and also the array of small invertebrates which fell from the blossoms when the branches were beaten and are assumed to be the target of foraging birds. Potentially pollinating insects from 29 Families within seven Orders were observed on flowering branches of $A$. dealbata (appendix 1). Of these, $41 \%$ of individuals were Dipterans (55\% of which were Syrphidae) (table 2a) and $41 \%$ were Hymenoptera (of which $38 \%$ were Honey 
Bees Apis mellifera and 15\% native bees). Coleoptera was a distant third in terms of frequency.

A diverse array of small invertebrates of varying developmental stages (appendix 1) was captured when flowering branches were beaten. In all, 47 Families from 10 Orders were represented but $94 \%$ of the total catch came from five Orders which each contributed between 11 and $25 \%$ (table $2 \mathrm{~b}$ ). Within the more common Orders the most numerous Families were: ColeopteraChrysomelidae (leaf beetles), Diptera- Chironomidae (Midges), Hemiptera- Psyllidae (psyllids), HymenopteraPlatygastridae (parasitoid wasps) and Araneae- Thomisidae (crab spiders). On the non-flowering tree, adjacent to flowering Tree 1, there was a reduced diversity of taxa. Over the four days when both trees were sampled, Tree 1 yielded 106 invertebrates from 19 families while the nonflowering tree collection was only 30 individuals from 11 Families (appendix 1).

\section{Bird visitors}

Across Sites 1 and 2 a total of ten bird species was seen to make contact with the inflorescences of $A$. dealbata trees during one or more of the 10-minute observation periods. A further 11 species perched on branches of $A$. dealbata trees but flew off without making contact with inflorescences or exhibiting feeding behaviour (table 3).

Of the ten species that contacted inflorescences, six did so only occasionally, briefly and incidentally, during the course of feeding on flowers of an adjacent Banksia marginata tree (Eastern Spinebill); hawking airborne insects around the tree crowns (Grey Fantail and Black-headed Honeyeater); or as a result of chasing or mating-related social behaviour (Yellow-throated Honeyeater, New Holland Honeyeater and Yellow Wattlebird).

Four bird species did actively work the flowering crowns of $A$. dealbata, moving between adjacent trees while doing so. On some days they remained in the crowns for the entire 10-minute observation period and beyond. Brown Thornbills and Silvereyes appeared to be searching for and feeding on small invertebrates (pl. 3) while the Green Rosellas and Eastern Rosellas were observed to feed within the blossom-bearing crowns, selectively picking and consuming individual pollen bearing and/or galled flowerheads (pl. 2). The presence of clipped branchlets on the ground below $97 \%$ of the trees at Site 1 (table 4) suggested that the Green Rosellas visited there more frequently than we were able to observe. Green Rosellas commenced visiting OPs at Site 1 once anthesis had commenced on some of the trees and were not observed on trees which were past peak flowering (fig. 1). Brown Thornbill visits were concentrated from early to peak flowering, but they also made a few visits before flowering commenced and after it had completed (fig. 1).

At Site 2, Silvereyes showed similar foraging behaviour to Brown Thornbills as did the Eastern Rosella to that of the Green Rosellas. At Site 3, Brown Thornbills were observed feeding among the $A$. dealbata flowers, moving from crown to crown during the 10-minute observation periods on seven of the ten observation days. Grey Fantails made accidental contact with the inflorescences on one day while hawking insects around the crowns. Although

TABLE 2a - Total flower visitors during 10-minute observation periods per tree on seven days throughout the 2018 flowering season.

\begin{tabular}{|c|c|c|c|c|c|c|c|c|c|}
\hline \multirow[b]{2}{*}{ Order } & \multirow[b]{2}{*}{ Family } & \multicolumn{7}{|c|}{ Observation Date } & \multirow[b]{2}{*}{ Total } \\
\hline & & $20 \mathrm{Jul}$ & 7 Aug & 14 Aug & 24 Aug & $4 \mathrm{Sep}$ & $11 \mathrm{Sep}$ & 18 Sep & \\
\hline \multirow[t]{2}{*}{ Diptera } & & 2 & 0 & 1 & 8 & 22 & 14 & 9 & 56 \\
\hline & (Syrphidae & 0 & 0 & 0 & 2 & 12 & 11 & 6 & 31) \\
\hline \multirow[t]{4}{*}{ Hymenoptera } & & 0 & 0 & 2 & 22 & 11 & 14 & 6 & 55 \\
\hline & (Apidae & 0 & 0 & 2 & 15 & 2 & 2 & 0 & 21) \\
\hline & (Halictidae & 0 & 0 & 0 & 2 & 1 & 1 & 2 & 6) \\
\hline & (Colletidae & 0 & 0 & 0 & 0 & 1 & 1 & 0 & 2) \\
\hline Coleoptera & & 0 & 0 & 3 & 1 & 3 & 7 & 2 & 16 \\
\hline Hemiptera & & 3 & 0 & 0 & 0 & 0 & 0 & 1 & 4 \\
\hline Lepidoptera & & 0 & 0 & 1 & 0 & 0 & 1 & 0 & 2 \\
\hline Neuroptera & & 1 & 0 & 0 & 0 & 0 & 0 & 0 & 1 \\
\hline Thysanoptera & & 0 & 0 & 0 & 0 & 0 & 1 & 0 & 1 \\
\hline Total & & 6 & 0 & 7 & 31 & 36 & 37 & 18 & 135 \\
\hline Flowering status & & 5 & 35 & 60 & 100 & 85 & 65 & 25 & - \\
\hline
\end{tabular}

${ }^{1}$ Mean $\%$ of flowers across sample trees which were judged to be fully opened $(100=$ peak flowering). Data from four trees were pooled. Within the total observations for Diptera and Hymenoptera the numbers for Families with highest putative pollination potential according to the literature are also detailed. For more complete data see appendix 2 . 
TABLE $2 \mathrm{~b}$ - Numbers of small invertebrates captured by beating flower-bearing branches throughout the 2018 flowering season.

\begin{tabular}{lcccccccccc}
\hline & \multicolumn{8}{c}{ Capture date } & \\
\cline { 2 - 6 } Order & 3 July & 9 Jul & 20 Jul & 7 Aug & 14 Aug & 24 Aug & 4 Sep & 11 Sep & 18 Sep & Total \\
Hymenoptera & 5 & 13 & 9 & 13 & 28 & 32 & 26 & 33 & 41 & 200 \\
Hemiptera & 12 & 24 & 13 & 18 & 13 & 24 & 16 & 23 & 26 & 169 \\
Diptera & 17 & 26 & 15 & 33 & 11 & 18 & 15 & 18 & 9 & 162 \\
Coleoptera & 3 & 11 & 7 & 9 & 12 & 26 & 22 & 15 & 17 & 122 \\
Araneae & 7 & 9 & 6 & 12 & 13 & 11 & 17 & 6 & 9 & 90 \\
Neuroptera & 0 & 2 & 1 & 3 & 3 & 3 & 6 & 1 & 3 & 22 \\
Acari & 1 & 0 & 1 & 2 & 2 & 5 & 3 & 0 & 0 & 14 \\
Thysanoptera & 0 & 0 & 0 & 0 & 2 & 0 & 4 & 2 & 0 & 8 \\
Lepidoptera & 0 & 0 & 0 & 1 & 1 & 0 & 2 & 1 & 2 & 7 \\
Blattodea & 0 & 0 & 0 & 0 & 0 & 0 & 0 & 0 & 2 & 2 \\
Total & 45 & $\mathbf{8 5}$ & $\mathbf{5 2}$ & $\mathbf{9 1}$ & $\mathbf{8 5}$ & $\mathbf{1 1 9}$ & $\mathbf{1 1 1}$ & $\mathbf{9 9}$ & $\mathbf{1 0 9}$ & $\mathbf{7 9 6}$ \\
Flowering status ${ }^{1}$ & 0 & 0 & 5 & 35 & 60 & 100 & 85 & 65 & 25 & - \\
\hline
\end{tabular}

${ }^{1}$ Mean $\%$ of flowers across sample trees which were judged to be fully opened (100 = peak flowering).

Data from four trees pooled. For details see appendix 1.

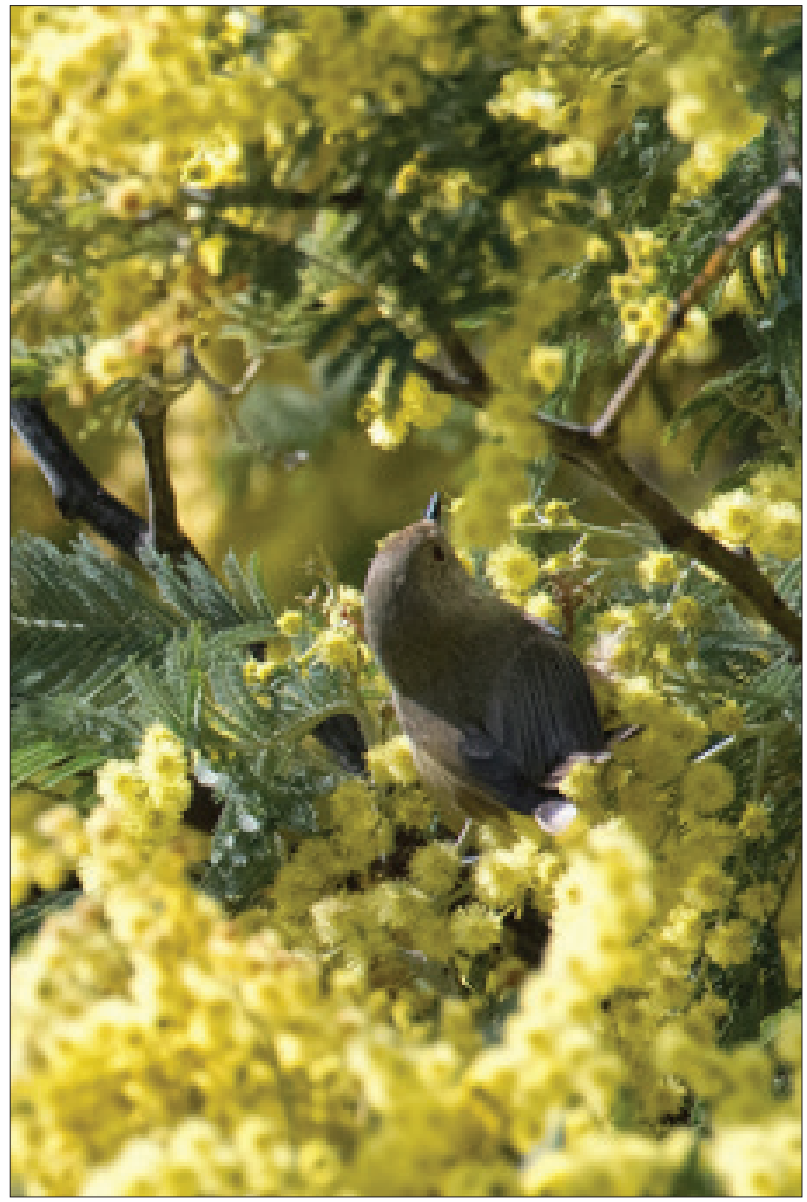

PLATE 3 - Brown Thornbill feeding within the blossom of A.dealbata (photo M. Brown).
Green Rosellas were not observed to visit the flowering crowns, the presence of clipped branchlets under $34 \%$ of nearby trees (table 4) indicated that they had made recent feeding visits.

\section{Indirect evidence of rosella feeding}

The surveys of clipped flowering branchlets on the ground below flowering $A$. dealbata trees at nine locations (table 4) suggested that Green Rosellas, and possibly Eastern Rosellas, fed on many of the trees. The proportion of trees below which clip could be detected ranged from 6\% at Waverley Flora Reserve to $97 \%$ at Site 1 , with a mean value across all nine sites of $57 \%$ (table 4 ).

\section{Pollen carried by birds}

Seventeen birds were caught and swabbed (10 at Site 1 over 3 days and 7 at Site 5 over 2 days) and nine of these carried pollen from various plants (tables $5 \mathrm{a}$ and $5 \mathrm{~b}$ ). Acacia polyads were recovered from five birds and on three of these (a Green Rosella and two Brown Thornbills) this was the only pollen present.

\section{Pollen viability on feathers}

The germination percentage of polyads experimentally placed on bird feathers was highest when freshly removed from the anthers. After $48 \mathrm{~h}$ incubation at ambient temperature, $60 \%$ had germinated (fig. 2). Thereafter viability declined more or less linearly to $16 \%$ at Day 12 , with no germination of the final sample taken at Day 17. 
TABLE 3 - Number per species for birds observed at two sites through the period of the study, indicating behavioural characteristics.

\begin{tabular}{|c|c|c|c|c|c|c|c|}
\hline \multirow[b]{2}{*}{ Common Name } & \multirow[b]{2}{*}{ Scientific name } & \multicolumn{3}{|c|}{ Site 1 - Knocklofty } & \multicolumn{3}{|c|}{ Site 2 - Mt Nelson } \\
\hline & & $\begin{array}{l}\text { Perching on } \\
\text { branches }\end{array}$ & $\begin{array}{l}\text { Contacting } \\
\text { flowers }\end{array}$ & $\begin{array}{l}\text { Feeding } \\
\text { on/ } \\
\text { among } \\
\text { inflor- } \\
\text { escences }\end{array}$ & $\begin{array}{l}\text { Perching } \\
\text { on } \\
\text { branches }\end{array}$ & $\begin{array}{l}\text { Contacting } \\
\text { flowers }\end{array}$ & $\begin{array}{l}\text { Feeding } \\
\text { on/ } \\
\text { among } \\
\text { inflor- } \\
\text { escences }\end{array}$ \\
\hline \multicolumn{8}{|l|}{ Psittaciformes } \\
\hline Green Rosella & Platycercus caledonicus & 19 & 19 & 19 & 19 & 19 & 19 \\
\hline Eastern Rosella & Platycercus eximius & - & - & - & 4 & 4 & 4 \\
\hline Musk Lorikeet & Glossopsitta concinna & - & - & - & 4 & - & - \\
\hline \multicolumn{8}{|l|}{ Passeriformes } \\
\hline Silvereye & Zosterops lateralis & - & - & - & 33 & 24 & 24 \\
\hline Brown Thornbill & Acanthiza pusilla & 14 & 14 & 14 & 5 & 5 & 5 \\
\hline $\begin{array}{l}\text { Yellow-throated } \\
\text { Honeyeater }\end{array}$ & Nesoptilotus flavicollis & 5 & * & - & 10 & $*$ & - \\
\hline Yellow Wattlebird & Anthochaera paradoxa & 6 & $*$ & - & 7 & $*$ & - \\
\hline $\begin{array}{r}\text { New Holland } \\
\text { Honeyeater }\end{array}$ & $\begin{array}{l}\text { Phylidonyris } \\
\text { novaehollandiae }\end{array}$ & - & - & - & 9 & $*$ & - \\
\hline $\begin{array}{l}\text { Crescent } \\
\text { Honeyeater }\end{array}$ & $\begin{array}{l}\text { Phylidonyris } \\
\text { pyrrhopterus }\end{array}$ & - & - & - & 1 & - & - \\
\hline Eastern Spinebill & $\begin{array}{c}\text { Acanthorhynchus } \\
\text { tenuirostris }\end{array}$ & 3 & $*$ & - & 4 & - & - \\
\hline $\begin{array}{r}\text { Black-headed } \\
\text { Honeyeater }\end{array}$ & Melithreptus affinis & 1 & - & - & 2 & * & - \\
\hline $\begin{array}{l}\text { Strong-billed } \\
\text { Honeyeater }\end{array}$ & $\begin{array}{l}\text { Melithreptus } \\
\text { validirostris }\end{array}$ & 2 & - & - & - & - & - \\
\hline Scarlet Robin & Petroica boodang & 7 & - & - & - & - & - \\
\hline Grey Fantail & Rhipidura albiscapa & 3 & * & - & - & - & - \\
\hline Superb Fairy-wren & Malurus cyaneus & 5 & - & - & - & - & - \\
\hline Grey Currawong & Strepera versicolor & 2 & - & - & 1 & - & - \\
\hline Grey Butcherbird & Cracticus torquatus & & - & - & 1 & - & - \\
\hline Forest Raven & Corvus tasmanicus & 1 & - & - & - & - & - \\
\hline Golden Whistler & Pachycephala pectoralis & 1 & - & - & - & - & - \\
\hline Grey Shrike-thrush & Colluricincla harmonica & 1 & - & - & - & - & - \\
\hline Common Blackbird & Turdus merula & 1 & - & - & 1 & - & - \\
\hline Not identified & & 7 & - & - & - & - & - \\
\hline
\end{tabular}

* incidental contact only 
TABLE 4 - Surveys of clip under $A$. dealbata trees at nine locations around Hobart, indicating feeding of Rosellas.

\begin{tabular}{lllccc}
\hline Transect No. & Date & \multicolumn{1}{c}{ Location } & $\begin{array}{c}\text { No. of trees with } \\
\text { clip under tree }\end{array}$ & $\begin{array}{c}\text { No. of trees } \\
\text { without clip }\end{array}$ & $\begin{array}{c}\text { Percentage of trees } \\
\text { with clip (\%) }\end{array}$ \\
\hline 1 & Aug 12 & Knockloftya (Site 1) & 31 & 1 & 97 \\
2 & Aug 13 & Peter Murrell Reserve & 36 & 6 & 86 \\
3 & Aug 17 & Waverley Flora Reserve & 2 & 29 & 6 \\
4 & Aug 18 & Geilston to Shag Bay walk & 2 & 21 & 9 \\
5 & Aug 28 & 31 Turnip Fields Rd (Site 4) & 32 & 34 & 48 \\
6 & Aug 29 & Lenah Valley Creek track & 51 & 20 & 72 \\
7 & Aug 29 & 30 Turnip Fields Rd (Site 4) & 16 & 15 & 52 \\
8 & Aug 30 & Cleggs Rd, Ferntree (Pipeline Track) & 20 & 8 & 71 \\
9 & Sep 02 & Lower Longley (Site 3) & 10 & 19 & 34 \\
& & Total & 200 & 153 & 57 \\
\hline
\end{tabular}

${ }^{1}$ Green Rosellas seen feeding on $A$. dealbata crowns at these locations at the time of survey.

TABLE 5a - Numbers of pollen grains observed on birds captured at Waterworks Reserve.

\begin{tabular}{lll}
\hline $\begin{array}{l}\text { Date } \\
(2018)\end{array}$ & \multicolumn{1}{c}{ Species } & \multicolumn{1}{c}{ Pollen } \\
\hline 22 Jul & Crescent Honeyeater & $\begin{array}{l}\text { 65 Banksia, 3 Pinus, } \\
1 \text { Eucalyptus? }\end{array}$ \\
$22 \mathrm{Jul}$ & Crescent Honeyeater & 334 Banksia \\
$22 \mathrm{Jul}$ & Scarlet Robin & 0 \\
$20 \mathrm{Aug}$ & Dusky Robin & 0 \\
20 Aug & Eastern Spinebill & 414 Ulex \\
20 Aug & Green Rosella & 15 Acacia \\
20 Aug & Crescent Honeyeater & 28 Banksia \\
\hline
\end{tabular}

TABLE 5b - Numbers of pollen grains observed on birds captured at Knocklofty Reserve.

\begin{tabular}{lll}
\hline $\begin{array}{l}\text { Date } \\
(2018)\end{array}$ & \multicolumn{1}{c}{ Species } & \multicolumn{1}{c}{ Pollen } \\
\hline 14 Aug & Superb Fairy-wren & 0 \\
14 Aug & Brown Thornbill & 0 \\
14 Aug & Brown Thornbill & 0 \\
14 Aug & Brown Thornbill & 0 \\
22 Aug & Crescent Honeyeater & 90 Ulex, 439 Melaleuca, \\
& & 6 Banksia, 2 Acacia \\
22 Aug & Yellow-throated & 6 Acacia, 9 Myrtaceae \\
& Honeyeater & 2 Acacia \\
22 Aug & Brown Thornbill & 6 Acacia \\
29 Aug & Brown Thornbill & 0 \\
29 Aug & Superb Fairy-wren & 0 \\
29 Aug & Superb Fairy-wren & 0 \\
\hline
\end{tabular}

TABLE 6 - Mean number of full seeds from pods harvested at three levels within the crowns of five trees at Site 4.

\begin{tabular}{lcccccc}
\hline & & \multicolumn{5}{c}{ Full seed/pod by crown position } \\
\cline { 3 - 7 } Tree & $\begin{array}{c}\text { Tree } \\
\text { ht }\end{array}$ & $\begin{array}{c}\text { Total } \\
\text { no. pods } \\
\text { extracted }\end{array}$ & $\begin{array}{c}\text { Low } \\
(\%)\end{array}$ & $\begin{array}{c}\text { Mid } \\
(\%)\end{array}$ & $\begin{array}{c}\text { Top } \\
(\%)\end{array}$ & $\begin{array}{c}\text { Weighted } \\
\text { mean }\end{array}$ \\
\hline \multirow{2}{*}{1} & 24 & 623 & 3.0 & 3.3 & 3.7 & 3.3 \\
& & & $\begin{array}{c}(84) \\
(75)\end{array}$ & $(67)$ & \\
2 & 13 & \multirow{2}{*}{521} & 3.1 & 3.8 & 3.9 & 3.6 \\
& & & $(70)$ & $(71)$ & $(72)$ & \\
3 & 15 & \multirow{2}{*}{808} & 1.3 & 1.4 & 1.4 & 1.4 \\
& & & $(43)$ & $(42)$ & $(43)$ & \\
4 & 19 & \multirow{2}{*}{817} & 3.6 & 3.5 & 3.9 & 3.7 \\
& & & $(62)$ & $(78)$ & $(82)$ & \\
5 & 20 & \multirow{2}{*}{1680} & 4.5 & 4.0 & 2.5 & 3.7 \\
& & & $(81)$ & $(77)$ & $64)$ & \\
\hline
\end{tabular}

Pooled data from two separate samples of pods at each level per tree, also expressed as a $\%$ of the total seed per pod. Differences between trees in number and $\%$ full seed significant, $\mathrm{p}<0.001$. No significant variation between levels within trees or tree $\mathrm{x}$ level interaction, $\mathrm{p}>0.05$.

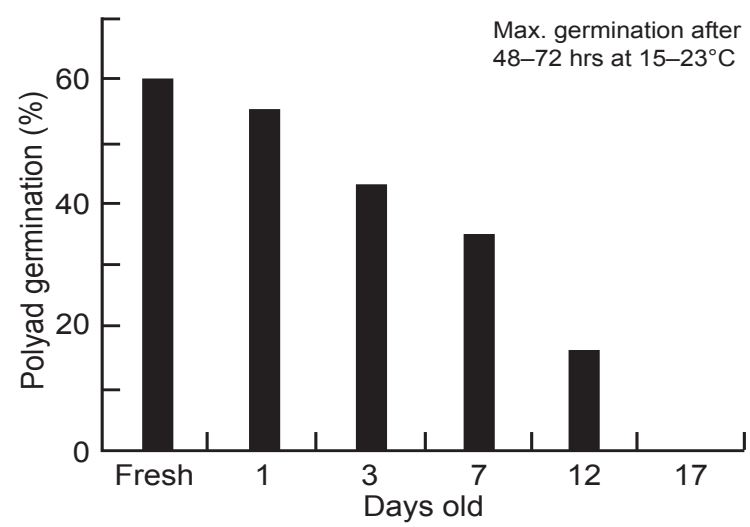

FIG. 2 - Viability over time of pollen placed on feathers at Day 0 and re-sampled at intervals up to 17 days. Material was kept dry and at ambient temperature. 


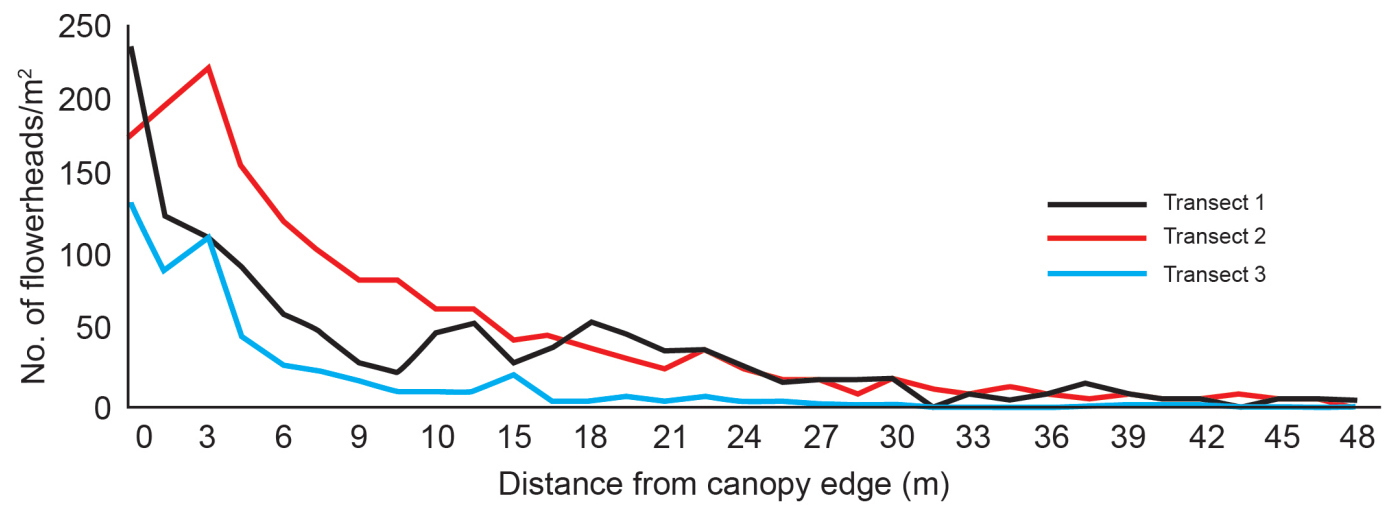

FIG. 3 - Dispersion of detached flower-heads on three transects run perpendicular to forest margin across open paddock at Site 4.

\section{Wind dispersal of flower-heads}

Head dispersal was surveyed on 17 August after a period of particularly windy weather. On the six previous days, maximum daily gusts at Ellerslie Rd ranged between 44 and $102 \mathrm{~km} \mathrm{~h}^{-1}$. For transects 1 and 2 which were perpendicular to the forest margin across open grassland, over $80 \%$ of heads fell within $15 \mathrm{~m}$ of the canopy margin, though occasional heads were still detected at the limit of observation $(49.5 \mathrm{~m})$ (fig. 3). The greater variability of Transect 3 could be attributable to the effect of several trees about $30 \mathrm{~m}$ away to the side of this transect.

\section{Pod and seed production}

Both flowering and mature pod production were essentially uniform within a tree crown as can be seen from the photographs of two trees which flowered heavily at Site 4 (pl. 1). Pod production from the very topmost branches is interesting in that it seems unlikely that, under the commonly prevailing weather conditions, these very exposed locations would be favoured as feeding sites by any of the insect visitors or even the birds; however, this is speculation. The mean number of full seed per pod was quite uniform among trees except for Tree 3 which was highly parasitised and only averaged 1.4 full seeds per pod, less than half the number of the nearby Trees 4 and 5 (table 6). Among the height levels in the crown there was no significant pattern of variation ( $p>0.05$, table 6). Although the pods from the top of Tree 5 had fewer seeds than lower in the canopy, it should be noted that this was the earliest maturing individual and it is possible that some seeds were already shedding from the dehiscing pods by the time we made the harvest.

The ovaries of $A$. dealbata flowers contain an average of 13 ovules (Correia et al. 2014). In the current study about one-third (4.26) were fertilised and developed to the point they could be classified as a seed, of which an average of $74 \%$ or 3.14 per pod were full.

\section{DISCUSSION}

The floral biology of $A$. dealbata is most closely aligned with an insect pollination syndrome; however, the weather conditions during the late winter/early spring flowering season are not conducive to insect flight activity and very few such visitors were observed until late in the flowering season (table 2a). It appears very unlikely that these numbers were sufficient to have a major impact as pollinators. A more objective determination of this point would require estimation of both flower numbers and the period over which individual stigmas remain receptive and is outside the scope of the present study. The introduced honey bee was the most common insect visitor, as was also the case where the species is growing as an exotic in South Africa (Rodger \& Johnson 2013), Portugal (Correia et al. 2014) and Italy (Giuliani et al. 2016 ), but the maximum number of individuals seen in a single observation period was only 15 across the four trees at the time of peak flowering (table 2a). As in an earlier study of three other species of Acacia in Tasmania (Hingston \& McQuillan 2000), small numbers of native bees, flies and beetles were also observed visiting the flowers. Of the native bees, which Bernhardt and Walker (1984) regarded as extremely significant pollinators of Acacia species, we observed only six individual Halictidae and two Colletidae over the whole study period. Stone et al. (2003) reported that over a range of Acacia species native bees represented only $1-5 \%$ of flower visits, so the generalisation regarding importance of native bees as pollinators is worth revisiting at least for cool temperate Australia. In a study of two spring/summer flowering Acacia species in Western NSW (Gilpin et al. 2014) only honey bees were found in high abundance and only they and two beetle species carried pollen on their bodies. Syrphid flies, also noted by Bernhardt (1989) as potentially important vectors, were the most common Dipteran visitors to the study trees (table 2a). A. dealbata is the earliest flowering of all Tasmanian acacias and if outcrossing by insects was of critical evolutionary importance then we might expect that selection pressure on the phenology would have caused a shift to later flowering. 
The species does not produce nectar from either flowers or extra-floral nectaries and this, together with the yellow flowers and distinctive scent, is inconsistent with traditional bird pollination syndromes which are characterised by the production of abundant nectar to support energetic needs, red colour, and little scent (Faegri \& van der Pijl 1979, Nadra et al. 2018). However, since some bird species were observed to consistently feed on and among the flowers (table 3) they must clearly be deriving some benefit. Brown Thornbills and Silvereyes have previously been documented working among flowers of other Acacia species (Ford \& Forde 1976, Knox et al. 1985, Vanstone \& Paton 1988), but in those cases they were feeding primarily from extrafloral nectaries which are vestigial in $A$. dealbata (Marazzi et al. 2019). However, Silvereyes and a Striated Thornbill Acanthiza lineata also occasionally pecked at flowers of $A$. pycnantha, and invertebrates and pollen were both suggested as the possible food items targeted (Ford \& Forde 1976, Vanstone \& Paton 1988). Our data clearly show that small invertebrates are a likely food source because of their abundance within inflorescences of $A$. dealbata. In a study in Victoria, Haylock and Lill (1988) found that thornbill diet was dominated by Coleoptera and Hymenoptera which we have shown are common on $A$. dealbata flowering branches at Site 1 (table 2a). The great majority of taxa we collected were within the size range of $<4 \mathrm{~mm}$ which Tullis et al. (1982) reported as making up $72 \%$ of the diet of two species of thornbill in Western Australia.

The importance of the micro-habitat of Acacia flowers to small invertebrates is evidenced by the greater diversity on flowering than non-flowering crowns (appendix 1). On a flowering tree $45 \%$ of the total catch was Chrysomelid beetles in larval form, Chironomid midges, and combfooted spiders (Theridiidae), but of these taxa, only two beetle larvae were present in samples from an adjacent non-flowering tree, where $50 \%$ of individuals were Psyllids. These differences are explainable in terms of feeding preferences. Larvae of some species of Chironomid may feed on pollen (Armitage et al. 1995); spiders presumably prey on other small invertebrates which are present in greater numbers on the flowering tree; many beetle larvae including Chrysomelids are adapted to consuming pollen (Bernhardt 1989) and can sometimes cause very significant damage to flowers of $A$. dealbata by eating the filaments, anthers and styles (Griffin unpubl. data). In contrast, the Psyllids are sap suckers and presumably vegetative shoots without flowers are also attractive to them. The seasonal pattern of occurrence of the small invertebrates was quite different to that of the larger insect flower visitors. Populations of the former were present within the inflorescences from well before flowering began (table 2b). These increased once trees began to flower, after which the total catch per day across the four sample trees was quite uniform through the rest of the season, though the maximum number was recorded at the time of peak flowering. In contrast very few potential pollinating insects were recorded until the trees reached peak flowering and numbers declined again towards the end of the season (table $2 \mathrm{a}$ ). The extended availability of small-invertebrate food explains why Brown Thornbills were also observed among the blossom throughout the complete season (fig. 1).

The foraging behaviour of Green Rosellas at flowers of $A$. dealbata was very different to that of Silvereyes and Brown Thornbills as they were observed to harvest and ingest whole flower-heads at a stage prior to complete anthesis (fig. 2). Several previously documented cases of bird pollination of nectarless flowers also reported that floral tissues were consumed (Sérsic \& Cocucci 1996, Dellinger et al. 2014, Nadra et al. 2018). We are unable to comment on the relative nutritional value of the floral components and/ or parasitising gall insects, but it is known that two other species of parrot occurring in our study region (Swift Parrot Lathamus discolor and Musk Lorikeet Glossopsitta concinna) intentionally consume and digest the pollen of Eucalyptus (Gartrell \& Jones 2001, Hingston et al. 2004a). Green and Eastern Rosellas both have been observed foraging on open flowers of Eucalyptus (Hingston \& Potts 2005), so the pollen is likely to be important as a food resource, a conclusion consistent with the decline in the bird visits at Site 1 after peak flowering (fig. 1). Magrath and Lill (1983) observed similar feeding behaviour in Crimson Rosellas $(P$. elegans) on eucalypts in Victoria, concluding that flower buds and associated gall larvae formed nearly $50 \%$ of their seasonal diet. These authors noted that, consistent with our observations, feeding rosellas always drop debris, so relative frequency of occurrence on the ground was used in estimating the diet in that study. Pollination by flowerconsuming Meyer's Parrots Poicephalus meyeri has also been documented in African 'acacias' (Boyes \& Perrin 2009).

Although these two rosella species are destructive foragers, they most likely pollinate numerous flowers as they clamber among the blossom and the prevalence of clippings beneath many flowering $A$. dealbata trees (table 4 ) shows that such activities are common and widespread. Given the mass flowering and characteristically low flower: fruit ratio in this and other Acacia species, the loss of some flowers may be an affordable price to pay for the pollination services provided by these species.

The feeding habits of these two functional groups of birds explains their presence in and among the flowers but to act as pollen vectors they must pick up pollen in the process. We were able to recover small amounts of Acacia pollen from the feathers of Green Rosellas and Brown Thornbills (table 5a, 5b) and have demonstrated that once pollen is removed from the anthers it can retain over half its viability for at least seven days (fig. 2), substantially longer than the three days reported by Sedgley and Harbard (1993) for tropical acacia taxa. Presumably this is time enough for birds to make many inter-tree visits before pollen viability is lost. Although both the number of birds sampled and the pollen recovered from those individuals was small, the data support the contention that these birds play a role in outcross pollination. The clip surveys (table 4) found that $57 \%$ of the $A$. dealbata trees across the region had been visited by rosellas which are strong-flying birds capable of many inter-tree movements. However, the numbers of individuals observed foraging on or among the flowers was 
small (table 3). Thornbills and Silvereyes were relatively more numerous at all three observation sites but it seems unlikely that either functional group could have been solely responsible for the total number of pollen transfer events needed to set the observed heavy fruit crop.

\section{Possibility of wind pollination}

Though the detached flowerheads have a substantial mass and over open ground were mostly deposited within $20 \mathrm{~m}$ of the crowns (fig. 3), this distance is more than enough for pollen transfer within stands of $A$. dealbata given the windy conditions which are prevalent during the flowering season in this region (Bureau of Meteorology 2018). It remains to be demonstrated that polyads are also blown off the open anthers under some conditions but the literature suggests that this is possible. Flowers of Acacia do not exhibit morphological traits normally characteristic of wind pollinated plants (Sedgley \& Griffin 1989, Gibson et al. 2011) and the polyads which average $46 \mu \mathrm{m}$ in diameter (Nghiem etal. 2018) are larger than the $25 \mu \mathrm{m}$ that is typical of the wind pollination syndrome (Knox 1979). However, as noted by Kendrick (2003), the disc shape of the polyad may have aerodynamic properties which serve to counteract their relatively large size. Reviews of the pollination ecology of the genus by Bernhardt (1989) and Stone et al. (2003) do not discuss the possibility but there are some records of wind dispersal of Acacia pollen (Moncur et al. 1991, Smart \& Knox 1979, Kendrick 2003, Giovanetti et al. 2018) and allergy to airborne pollen has been reported from a number of countries (Ariano et al. 1991). Millar et al. (2014) offered long-distance wind-mediated dispersal of small insects as an explanation for their finding of substantial gene flow between dispersed populations of $A$. woodmaniorum in Western Australia. While Keighery (1980) listed Acacia as being primarily insect pollinated in that region, he acknowledged that bird and wind transference could play a minor role in pollination and noted that "more observations are needed on (pollen vectors) of this important genus".

Factors determining efficiency of wind pollination are very different from those with biotic vectors. There is no issue of population number in pollen transfer since wind is a more or less general phenomenon in the region during the flowering season of $A$. dealbata. While biotic vectors would target flowers during feeding, wind dispersion is effectively random in space but with density in the air as the major determinant of the probability that a polyad would land on a receptive style. It is likely that geitonogamous pollination (transfer of pollen between flowers within a single genet) within a tree crown or between ramets of a clone would be a much more frequent outcome than transfer between different genets, so impact of vector type on the breeding system needs to be considered.

Studies of the species as an exotic in South Africa (Rodger $\&$ Johnson 2013) and Portugal (Correia et al. 2014) found that $A$. dealbata is partially self-fertile and demonstrated that autonomous pollination is possible (see also review by Gibson 2011), although Broadhurst et al. (2008) found that only outcrossed seed were produced under natural pollination conditions in populations of the species in New South Wales. Mechanisms favouring preferential development of outcrosses may operate in Acacia as in Eucalyptus (Griffin et al. 1987) but this remains to be demonstrated. If the plants are strongly reliant on biotic outcross pollination in order to set seed and pollinators are scarce relative to the large number of flowers produced, then we would expect to see a patchy distribution of pods within each tree crown. The pod and seed production data are therefore useful in gaining an appreciation of the likelihood of such pollen limitation. We were not able to quantify total flower or pod crops per tree but it was evident from inspection that pod set in 2018 was generally both heavy and uniformly distributed within the crowns to the very topmost branches (Plate 1 and table 6). The consistent uniformity of production of full seed pods throughout the crown (table 6) strengthens the possibility that wind pollination may be important and is in contrast to Eucalyptus globulus, a common dominant tree species in southeast Tasmania which is known to be pollinated by both birds and insects (Hingston et al. 2004b). In that species Hingston and Potts (2005) found significantly less flower-visiting bird activity in the lower than higher halves of the crowns and Patterson et al. (2004) showed this pattern was associated with higher outcrossing rates for the seeds from the upper part of the canopy. In our study, observed population mean number of full seeds per pod of 3.14 (table 6) is substantially higher than the maximum mean of 1.2 found in the ten NSW populations studied by Broadhurst and Young (2006), or the 1.04 in an exotic population in South Africa (Rodger \& Johnson 2013) and can be taken as another indication of probable high levels of outcrossing. Genetic analysis of seed samples from Site 4, to be published elsewhere, has confirmed this assumption. The mating system is definitely strongly outcrossing $(\mathrm{t}=$ $0.89 \pm 0.92$ ) (R. Vaillancourt unpubl. data).

In summary, the study failed to definitively identify any one major pollinator of $A$. dealbata in this environment yet we infer from the heavy and uniformly distributed pod crops and from the genetic analysis, that outcrossing must be occurring. The species is best viewed as having a generalist pollination system, a conclusion reached by the study of Montesinos et al. (2016) in exotic populations in Portugal and consistent with many other plant species in southern Tasmania (Hingston \& McQuillan 2000). Evolution of reproductive attributes amenable to pollination by a range of different vectors may be of adaptive advantage (Hingston \& McQuillan 2000, Ollerton et al. 2009), with the consequence that current major pollen vectors cannot be predicted from consideration of floral traits alone.

\section{ACKNOWLEDGEMENTS}

The authors wish to acknowledge Elise Jefferies of Hobart City Council for permission to conduct the studies at Knocklofty Reserve, Astrid Wright of the Friends of Knocklofty for access to historical records of vegetation management, Dr David Paton for advice on bird observa- 
tions, and Geoff and Janet Fenton for bird data from Longley. Mist-netting was conducted under the following permits held by CMY: Animal Ethics approval from University of Tasmania (A0015838), Australian Bird and Bat Banding Scheme project licence (2833-1), scientific permit from the Tasmanian Department of Primary Industry, Parks, Water and Environment (FA 18153) and Hobart City Council research permit (03-2018). We also thank the anonymous reviewer for their helpful comments.

\section{REFERENCES}

Ariano, R., Panzani, R.C. \& Amedeo, J. 1991: Pollen allergy to Mimosa (Acacia-floribunda) in a mediterranean area - an occupational-disease. Annals of Allergy 66: 253-256.

Armitage, P.D., Cranston, P.S. \& Pinder, L.C.V. 1995: The Chironomidae: biology and ecology of non-biting midges. Chapman \& Hall, London: 572 pp.

Bernhardt, P. 1987: A comparison of the diversity, density, and foraging behavior of bees and wasps on Australian Acacia. Annals of the Missouri Botanical Garden 74: 42-50.

Bernhardt, P. 1989: The floral ecology of Australian Acacia. In Stirton, C.H. \& Zarucchi, J.L. (eds.): Advances in Legume Biology. Monographs in Systematic Botany from the Missouri Botanical Garden 29: 263-281.

Bernhardt, P. \& Walker, K. 1984: Bee foraging on 3 sympatric species of Australian Acacia. International Journal of Entomology 26: 322-330.

Boland, D., Brooker, M., Chippendale, G., Hall, N., Hyland, B., Johnston, R., Kleinig, D., McDonald, M. \& Turner, J. 2006: Forest trees of Australia (Fifth Edition), CSIRO, Melbourne: $568 \mathrm{pp}$

Bureau of Meteorology 2018: 'Hobart, Tas - Daily Weather Observations.' Available at: http://www.bom.gov.au/ climate/dwo/IDCJDW7021.latest.shtml

Boughton, V. 1981: Extrafloral nectaries of some Australian phyllodineous Acacias. Australian Journal of Botany 29: 653-664.

Boyes, R.S. \& Perrin, M.R. 2009: Do Meyer's Parrots Poicephalus meyeri benefit pollination and seed dispersal of plants in the Okavango Delta, Botswana? African Journal of Ecology 48, 769-782.

Broadhurst, L.M. \& Young, A.G. 2006: Reproductive constraints for the long-term persistence of fragmented Acacia dealbata (Mimosaceae) populations in southeast Australia. Biological Conservation 133: 512-526.

Broadhurst, L.M., Young, A.G. \& Forrester, R. 2008: Genetic and demographic responses of fragmented Acacia dealbata (Mimosaceae) populations in southeastern australia. Biological Conservation 141: 2843-2856.

Correia, M., Castro, S., Ferrero, V., Crisóstomo, J.A. \& Rodríguez-Echeverría, S. 2014: Reproductive biology and success of invasive Australian Acacias in Portugal. Botanical Journal of the Linnean Society 174: 574-588.

Dellinger, A.S., Penneys, D.S., Staedler, Y.M., Fragner, L., Weckwerth, W. \& Schönenberger, J. 2014: A specialized bird pollination system with a bellows mechanism for pollen transfer and staminal food body rewards. Current Biology 24: 1615-1619.

Faegri, K. \& van der Pijl, L. 1979: The Principles of Pollination Ecology. Pergamon Press, Oxford: 244 pp.

Ford, H.A. \& Forde, N. 1976: Birds as possible pollinators of Acacia pycnantha. Australian Journal of Botany 24: 793-795.

Ford, H.A., Paton, D.C. \& Forde, N. 1979: Birds as pollinators of Australian plants. New Zealand Journal of Botany 17: 509-519.
Fuentes-Ramirez, A., Pauchard, A., Cavieres, L.A. \& Garcia, R.A. 2011: Survival and growth of Acacia dealbata vs. native trees across an invasion front in south-central Chile. Forest Ecology and Management 261: 1003-1009.

Gartrell, B.D. \& Jones, S.M. 2001: Eucalyptus pollen grain emptying by two Australian nectarivorous psittacines. Journal of Avian Biology 32: 224-230.

Gibson, M.R., Richardson, D.M., Marchante, E., Marchante, H., Rodger, J.G., Stone, G.N., Byrne, M., Fuentes-Ramírez, A., George, N., Harris, C., Johnson, S.D., Roux, J.J.L., Miller, J.T., Murphy, D.J., Pauw, A., Prescott, M.N., Wandrag, E.M. \& Wilson, J.R.U. 2011: Reproductive biology of Australian Acacias: Important mediator of invasiveness? Diversity and Distributions 17: 911-933.

Gilpin, A.M., Ayre, D.J. \& Denham, A.J. 2014: Can the pollination biology and floral ontogeny of the threatened Acacia carneorum explain its lack of reproductive success? Ecological Research 29: 225-235.

Giovanetti, M., Ramos, M. \& Máguas, C. 2018: Why so many flowers? A preliminary assessment of mixed pollination strategy enhancing sexual production of the invasive Acacia longifolia in Portugal. Web Ecology 18: 47-54.

Giuliani, C., Giovanetti, M., Foggi, B. \& Mariotti Lippi, M. 2016: Two alien invasive acacias in Italy: Differences and similarities in their flowering and insect visitors. Plant Biosystems - An International Journal Dealing with all Aspects of Plant Biology 150: 285-294.

Griffin, A.R., Moran, G.F. \& Fripp, Y.J. 1987: Preferential outcrossing in Eucalyptus regnans F.Muell. Australian Journal of Botany 35: 465-475

Griffin, A.R., Hingston, A.B. \& Ohmart, C.P. 2009: Pollinators of Eucalyptus regnans (Myrtaceae), the world's tallest flowering plant species. Australian Journal of Botany 57: 18-25.

Griffin, A.R, Midgley, S., Bush, D., Cunningham, P. \& Rinaudo, A. 2011: Global uses of Australian acacias-recent trends and future prospects. Diversity and Distributions 17: 837-847.

Harwood, C.E., Griffin, A.R., Harbard, J.L. \& Nghiem, Q.C. 2018: Studies on triploid clones of Silver Wattle (Acacia dealbata) in southeast Tasmania. The Tasmanian Naturalist 140: $107-123$.

Haylock, J. \& Lill, A. 1988: Winter ecological energetics of 2 passerine bird species in temperate wet forest. Wildlife Research 15: 319 -329.

Hingston, A.B. \& McQuillan, P.B. 2000: Are pollination syndromes useful predictors of floral visitors in Tasmania? Austral Ecology 25: 600-609.

Hingston, A.B., Gartrell, B.D. \& Pinchbeck, G. 2004a: How specialized is the plant-pollinator association between Eucalyptus globulus ssp. globulus and the swift parrot Lathamus discolor? Austral Ecology 29: 624--630.

Hingston, A.B., Potts, B.M. \& McQuillan, P.B. 2004b: Pollination services provided by various size classes of flower visitors to Eucalyptus globulus ssp globulus (Myrtaceae). Australian Journal of Botany 52: 353-369.

Hingston, A.B. \& Potts, B.M. 2005: Pollinator activity can explain variation in outcrossing rates within individual trees. Austral Ecology 30: 319-324.

Keighery, G.J. 1980: Bird pollination in south western Australia: A checklist. Plant Systematics and Evolution 135: 171-176.

Kendrick, J. 2003: Review of pollen-pistil interactions and their relevance to the reproductive biology of Acacia. Australian Systematic Botany 16: 119-130.

Kitchener, A. \& Harris, S. 2013: From forest to fjaeldmark: Descriptions of Tasmania's vegetation, Department of Primary Industries, Parks, Water and Environment, Tasmania: $14 \mathrm{pp}$.

Knox, R.B. 1979: 'Pollen and Allergy' Studies in Biology No. 107, Edward Arnold Ltd., London: 64 pp.

Knox, R.B., Kenrick, J., Bernhardt, P., Marginson, R., Beresford, G., Baker, I. \& Baker, H.G. 1985: Extrafloral nectaries 
as adaptations for bird pollination in Acacia terminalis. American Journal of Botany 72: 1185-1196.

Magrath, R. \& Lill, A. 1983: The use of time and energy by the Crimson Rosella in a temperate wet forest in winter. Australian Journal of Zoology 31: 903-912.

Marazzi, B., Gonzalez, A.M., Delgado-Salinas, A., Luckow, M.A., Ringelberg, J.J. \& Hughes, C.E. 2019: Extrafloral nectaries in leguminosae: Phylogenetic distribution, morphological diversity and evolution. Australian Systematic Botany 32: 409-458.

Millar, M.A., Coates, D.J. \& Byrne, M. 2014: Extensive longdistance pollen dispersal and highly outcrossed mating in historically small and disjunct populations of Acacia woodmaniorum (fabaceae), a rare banded iron formation endemic. Annals of Botany 114: 961-971.

Moncur, M.W., Moran, G.F. \& Grant, J.E. 1991: Factors limiting seed production in Acacia mearnsii. Advances in Tropical Acacia Research 35: 20-25.

Montesinos, D., Castro, S. \& Rodríguez-Echeverría, S. 2016: Two invasive Acacia species secure generalist pollinators in invaded communities. Acta Oecologica 74: 46-55.

Nadra, M.G., Giannini, N.P., Acosta, J.M. \& Aagesen, L. 2018: Evolution of pollination by frugivorous birds in Neotropical Myrtaceae. PeerJ 6, e5426.

Nghiem, Q., Griffin, A., Harwood, C., Harbard, J., Le, S., Price, A. \& Koutoulis, A. 2018: Occurrence of polyploidy in populations of Acacia dealbata in south-eastern Tasmania and cytotypic variation in reproductive traits. Australian Journal of Botany 66: 152-160.

Ollerton J, Alarcón R, Waser, N.M., Price, M.V., Watts, S., Cranmer, L., Hingston, A., Peter, C.I. \& Rotenberry, J. 2009: A global test of the pollination syndrome hypothesis. Annals of Botany 103: 1471-1480.

Patterson, B., Vaillancourt, R.E., Pilbeamb, D.J. \& Potts, B.M. 2004: Factors affecting variation in outcrossing rate in Eucalyptus globulus. Australian Journal of Botany 52: 773-780.

Rodger, J.G. \& Johnson, S.D. 2013: Self-pollination and inbreeding depression in Acacia dealbata: Can selfing promote invasion in trees? South African Journal of Botany 88: 252-259.

Rosas-Guerrero, V., Aguilar, R., Martén-Rodríguez, S., Ashworth, L., Lopezaraiza-Mikel, M., Bastida, J.M. \& Quesada, M. 2014: A quantitative review of pollination syndromes: do floral traits predict effective pollinators? Ecology Letters 17: 388-400.

Sargent, O.H. 1928: Reactions between birds and plants. EmuAustral Ornithology 27: 185-192.

Sedgley, M. \& Griffin, A.R. 1989: Sexual Reproduction of Tree Crops, Academic Press, London: 378 pp.

Sedgley, M. \& Harbard, J.L. 1993: Pollen storage and breeding system in relation to controlled pollination of 4 species of Acacia (Leguminosae, Mimosoideae). Australian Journal of Botany 41: 601-609.

Sérsic, A.N. \& Cocucci, A. 1996: A remarkable case of ornithophily in Calceolaria: food bodies as rewards for a non-nectarivorous bird. Botanica Acta 109: 172-176.

Smart, I. \& Knox, R. 1979: Aerobiology of grass pollen in the city atmosphere of Melbourne: quantitative analysis of seasonal and diurnal changes. Australian Journal of Botany 27: 317-331.

Stone, G.N., Raine, N.E., Prescott, M. \& Willmer, P.G. 2003: Pollination ecology of Acacias (Fabaceae, Mimosoideae). Australian Systematic Botany 16: 103-118.

Tullis, K., Calver, M. \& Wooller, R. 1982: The invertebrate diets of small birds in Banksia woodland near Perth, W.A., during winter. Wildlife Research 9: 303-309.

Vanstone, V.A. \& Paton, D.C. 1988: Extrafloral nectaries and pollination of Acacia pycnantha Benth. by birds. Australian Journal of Botany 36: 519-531.

Wandrag, E.M., Sheppard, A.W., Duncan, R.P. \& Hulme, P.E. 2015: Pollinators and predators at home and away: do they determine invasion success for Australian Acacia in New Zealand? Journal of Biogeography 42: 619-629.

(accepted 22 July 2020) 
APPENDIX 1

Invertebrate survey data from branch beating and observation on four flowering trees and one non-flowering tree. ${ }^{1}$ Total numbers across all trees and seven observation dates.

\begin{tabular}{|c|c|c|c|c|c|c|c|c|}
\hline Class & Order & Family & Common name & State & $\begin{array}{l}\text { Invertebrates } \\
\text { BEATING } \\
\text { (non- } \\
\text { flowering } \\
\text { tree) }\end{array}$ & $\begin{array}{l}\text { Invertebrates } \\
\text { BEATING } \\
\text { (flowering) }\end{array}$ & $\begin{array}{l}\text { Invertebrates } \\
\text { OBSERVED } \\
\text { (flowering) }\end{array}$ & $\begin{array}{c}\text { Total } \\
\text { (flowering } \\
\text { trees only) }\end{array}$ \\
\hline Insecta & Blattodea & Ectobiidae & Cockroach & Adult & 0 & 2 & 0 & 2 \\
\hline Insecta & Coleoptera & Attelabidae & $\begin{array}{l}\text { Leaf rolling } \\
\text { weevils }\end{array}$ & Adult & 0 & 2 & 0 & 2 \\
\hline Insecta & Coleoptera & Cerambycidae & Longicorns & Adult & 0 & 0 & 1 & 1 \\
\hline Insecta & Coleoptera & Chrysomelidae & Leaf beetles & $\begin{array}{l}\text { Adult/ } \\
\text { Larvae }\end{array}$ & 2 & 61 & 6 & 67 \\
\hline Insecta & Coleoptera & Cleridae & Clerid beetles & Adult & 0 & 2 & 0 & 2 \\
\hline Insecta & Coleoptera & Coccinellidae & Ladybirds & Adult & 0 & 23 & 1 & 24 \\
\hline Insecta & Coleoptera & Curculionidae & Weevils & Adult & 0 & 0 & 1 & 1 \\
\hline Insecta & Coleoptera & Latridiidae & $\begin{array}{l}\text { Minute } \\
\text { scavenger beetle }\end{array}$ & Adult & 0 & 30 & 0 & 30 \\
\hline Insecta & Coleoptera & Nitidulidae & Sap beetles & Adult & 0 & 3 & 0 & 3 \\
\hline Insecta & Coleoptera & Scarabaeidae & Scarab beetles & Adult & 0 & 0 & 7 & 7 \\
\hline Insecta & Coleoptera & Tenebrionidae & Darkling beetles & Adult & 0 & 1 & 0 & 1 \\
\hline Insecta & Diptera & $\begin{array}{l}\text { cf. } \\
\text { Anthomyiidae }\end{array}$ & $\begin{array}{l}\text { Root maggot } \\
\text { flies }\end{array}$ & Adult & 0 & 0 & 1 & 1 \\
\hline Insecta & Diptera & Cecidomyiidae & Gall midges & Adult & 0 & 9 & 0 & 9 \\
\hline Insecta & Diptera & Chironomidae & Midges & Adult & 0 & 106 & 19 & 125 \\
\hline Insecta & Diptera & Chloropidae & Frit flies & Adult & 0 & 9 & 0 & 9 \\
\hline Insecta & Diptera & Empididae & Dance flies & Adult & 0 & 5 & 0 & 5 \\
\hline Insecta & Diptera & Lauxaniidae & Lauxaniid flies & Adult & 0 & 0 & 1 & 1 \\
\hline Insecta & Diptera & Phoridae & Scuttle flies & Adult & 1 & 3 & 0 & 3 \\
\hline Insecta & Diptera & Sciaridae & Fungus gnats & Adult & 0 & 15 & 1 & 16 \\
\hline Insecta & Diptera & Syrphidae & Hoverflies & Adult & 0 & 7 & 31 & 38 \\
\hline Insecta & Diptera & Tachinidae & Tachinid flies & Adult & 0 & 0 & 3 & 3 \\
\hline Insecta & Diptera & $\begin{array}{l}\text { Diptera } \\
\text { Unknown }\end{array}$ & & Adult & 0 & 8 & 0 & 8 \\
\hline Insecta & Hemiptera & cf. Callipappidae & $\begin{array}{l}\text { Bird of paradise } \\
\text { flies }\end{array}$ & Adult & 0 & 0 & 1 & 1 \\
\hline Insecta & Hemiptera & Cicadellidae & Leafhoppers & $\begin{array}{l}\text { Adult/ } \\
\text { nymph }\end{array}$ & 3 & 7 & 0 & 7 \\
\hline Insecta & Hemiptera & Miridae & Plant bugs & $\begin{array}{l}\text { Adult/ } \\
\text { nymph }\end{array}$ & 1 & 75 & 1 & 76 \\
\hline Insecta & Hemiptera & Monophlebidae & Giant scales & Adult & 0 & 0 & 1 & 1 \\
\hline Insecta & Hemiptera & Pentatomidae & Shield bugs & Adult & 0 & 0 & 1 & 1 \\
\hline Insecta & Hemiptera & Pseudococcidae & Mealy bugs & Adult & 0 & 3 & 0 & 3 \\
\hline Insecta & Hemiptera & Psyllidae & Psyllids & $\begin{array}{l}\text { Adult/ } \\
\text { nymph }\end{array}$ & 16 & 74 & 0 & 74 \\
\hline Insecta & Hemiptera & Reduviidae & Assasin bugs & Adult & 0 & 1 & 0 & 1 \\
\hline Insecta & Hemiptera & Tingidae & Lace bugs & Adult & 0 & 9 & 0 & 9 \\
\hline
\end{tabular}




\begin{tabular}{|c|c|c|c|c|c|c|c|c|}
\hline Class & Order & Family & Common name & State & $\begin{array}{c}\text { Invertebrates } \\
\text { BEATING } \\
\text { (non- } \\
\text { flowering } \\
\text { tree) }\end{array}$ & $\begin{array}{l}\text { Invertebrates } \\
\text { BEATING } \\
\text { (flowering) }\end{array}$ & $\begin{array}{c}\text { Invertebrates } \\
\text { OBSERVED } \\
\text { (flowering) }\end{array}$ & $\begin{array}{c}\text { Total } \\
\text { (flowering } \\
\text { trees only) }\end{array}$ \\
\hline Insecta & Hymenoptera & Apidae & Bees & Adult & 0 & 0 & 21 & 21 \\
\hline Insecta & Hymenoptera & Bethylidae & Aculeate wasps & Adult & 0 & 2 & 0 & 2 \\
\hline Insecta & Hymenoptera & Braconidae & Braconid wasps & Adult & 0 & 5 & 2 & 7 \\
\hline Insecta & Hymenoptera & Colletidae & $\begin{array}{l}\text { Short-tongued } \\
\text { bees }\end{array}$ & Adult & 0 & 1 & 2 & 3 \\
\hline Insecta & Hymenoptera & Diapriidae & Parasitoid wasps & Adult & 1 & 1 & 0 & 1 \\
\hline Insecta & Hymenoptera & Encyrtidae & Parasitoid wasps & Adult & 1 & 7 & 0 & 7 \\
\hline Insecta & Hymenoptera & Eulophidae & Parasitoid wasps & Adult & 0 & 12 & 1 & 13 \\
\hline Insecta & Hymenoptera & Formicidae & Ants & Adult & 1 & 11 & 2 & 13 \\
\hline Insecta & Hymenoptera & Halictidae & Burrowing bees & Adult & 0 & 0 & 6 & 6 \\
\hline Insecta & Hymenoptera & Ichneumonidae & $\begin{array}{l}\text { Ichneumon } \\
\text { wasps }\end{array}$ & Adult & 0 & 0 & 11 & 11 \\
\hline Insecta & Hymenoptera & Platygastridae & Parasitoid wasps & Adult & 1 & 146 & 1 & 147 \\
\hline Insecta & Hymenoptera & Pteromalidae & Parasitoid wasps & Adult & 1 & 9 & 0 & 9 \\
\hline Insecta & Hymenoptera & Tiphiidae & Flower wasps & Adult & 0 & 0 & 2 & 2 \\
\hline Insecta & Hymenoptera & $\begin{array}{l}\text { Hymenoptera } \\
\text { Unknown }\end{array}$ & & Adult & 0 & 6 & 7 & 13 \\
\hline Insecta & Lepidoptera & Geometridae & Loopers & Larvae & 0 & 1 & 0 & 1 \\
\hline Insecta & Lepidoptera & Lymantriidae & Tussock moths & Larvae & 0 & 1 & 2 & 3 \\
\hline Insecta & Lepidoptera & Oecophoridae & Concealer moths & Adult & 0 & 1 & 0 & 1 \\
\hline Insecta & Lepidoptera & $\begin{array}{l}\text { Lepidoptera } \\
\text { Unknown }\end{array}$ & & Larvae & 0 & 4 & 0 & 4 \\
\hline Insecta & Neuroptera & Chrysopidae & Green lacewing & Larvae & 0 & 1 & 0 & 1 \\
\hline Insecta & Neuroptera & Coniopterygidae & Dusty wings & Adults & 0 & 18 & 1 & 19 \\
\hline Insecta & Neuroptera & Hemerobiidae & Brown lacewings & Larvae & 0 & 3 & 0 & 3 \\
\hline Insecta & Thysanoptera & $\begin{array}{l}\text { Thysanoptera } \\
\text { Unknown }\end{array}$ & Thrips & Adult & 0 & 8 & 1 & 9 \\
\hline Araneae & & Araneidae & Orb weavers & $\begin{array}{l}\text { Adult/ } \\
\text { spiderlings }\end{array}$ & 0 & 1 & 0 & 1 \\
\hline Araneae & & Clubionidae & Sac spiders & $\begin{array}{l}\text { Adult/ } \\
\text { spiderlings }\end{array}$ & 0 & 2 & 0 & 2 \\
\hline Araneae & & Salticidae & Jumping spiders & $\begin{array}{c}\text { Adult/ } \\
\text { spiderlings }\end{array}$ & 0 & 1 & 0 & 1 \\
\hline Araneae & & Theridiidae & $\begin{array}{l}\text { Comb-footed } \\
\text { spiders }\end{array}$ & $\begin{array}{c}\text { Adult/ } \\
\text { spiderlings }\end{array}$ & 0 & 33 & 0 & 33 \\
\hline Araneae & & Thomisidae & Crab spiders & $\begin{array}{c}\text { Adult/ } \\
\text { spiderlings }\end{array}$ & 0 & 46 & 1 & 47 \\
\hline Araneae & & $\begin{array}{l}\text { Araneae } \\
\text { Unknown }\end{array}$ & & $\begin{array}{c}\text { Adult/ } \\
\text { spiderlings }\end{array}$ & 2 & 7 & 0 & 7 \\
\hline Acari & & Unknown & Mites & & 2 & 14 & 0 & 14 \\
\hline
\end{tabular}

${ }^{1}$ For photographic records of most taxa by K. Ellison see: https://www.flickr.com/photos/zosterops/albums/72157698885625455/page1 
APPENDIX 2

Daily records of bird species observed visiting $A$. dealbata crowns over a 10 -minute observation period at each of five observation points at Knocklofty (Site 1). Ambient conditions and flowering status of observed trees are shown for each observation point.

\begin{tabular}{|c|c|c|c|c|c|c|c|c|c|c|c|c|c|c|c|c|c|c|}
\hline \multirow{2}{*}{$\begin{array}{l}\text { Obs. } \\
\text { point }\end{array}$} & \multirow{2}{*}{$\begin{array}{l}\text { Bird species and } \\
\text { flowering }\end{array}$} & \multicolumn{17}{|c|}{ Days from start (26 June) } \\
\hline & & 1 & 6 & 14 & 21 & 28 & 34 & 40 & 43 & 49 & 57 & 61 & 65 & 70 & 77 & 87 & 92 & 95 \\
\hline \multirow[t]{5}{*}{1} & Brown Thornbill & - & - & - & - & - & - & - & - & - & - & - & - & - & - & - & - & - \\
\hline & $\begin{array}{l}\text { Yellow } \\
\text { Wattlebird }\end{array}$ & - & - & - & - & - & - & 1 & - & - & - & - & - & - & 2 & - & - & - \\
\hline & $\begin{array}{l}\text { Yellow-throated } \\
\text { Honeyeater }\end{array}$ & 1 & - & - & - & - & 1 & - & 1 & - & - & - & - & - & - & - & - & - \\
\hline & Other & 2 & - & - & 1 & - & - & - & 1 & 1 & - & - & - & - & - & - & - & - \\
\hline & $\begin{array}{l}\text { Flowering } \\
\text { (\% receptive) }\end{array}$ & 0 & 0 & 0 & 0 & 0 & 0 & 2 & 5 & 20 & 70 & 90 & 90 & 20 & 10 & 0 & 0 & 0 \\
\hline \multirow[t]{5}{*}{2} & Brown Thornbill & - & - & - & - & - & - & - & - & - & - & 2 & 2 & - & - & - & - & - \\
\hline & Green Rosella & - & - & - & - & - & - & 6 & - & 4 & - & - & - & - & - & - & - & - \\
\hline & $\begin{array}{l}\text { Yellow } \\
\text { Wattlebird }\end{array}$ & - & - & - & - & 1 & - & - & - & - & - & - & - & - & - & - & - & - \\
\hline & Other & 1 & 1 & 1 & - & - & - & - & - & - & - & - & 1 & - & - & - & - & - \\
\hline & $\begin{array}{l}\text { Flowering } \\
\text { (\% receptive) }\end{array}$ & 0 & 0 & 0 & 0 & 0 & 1 & 2 & 2 & 15 & 20 & 50 & 70 & 80 & 20 & 2 & 0 & 0 \\
\hline \multirow[t]{5}{*}{3} & Brown Thornbill & - & - & - & - & - & 2 & - & - & - & - & - & - & - & - & - & - & - \\
\hline & Green Rosella & - & - & - & - & - & - & 1 & - & - & - & - & - & - & - & - & - & - \\
\hline & $\begin{array}{l}\text { Yellow-throated } \\
\text { Honeyeater }\end{array}$ & - & - & - & - & - & - & - & - & - & - & - & - & - & 1 & - & - & 1 \\
\hline & Other & - & - & - & - & - & - & - & - & - & - & - & - & 1 & - & - & - & - \\
\hline & $\begin{array}{l}\text { Flowering } \\
\text { (\% receptive) }\end{array}$ & 0 & 0 & 0 & 1 & 20 & 30 & 80 & 100 & 50 & 50 & 10 & 10 & 10 & 10 & 0 & 0 & 0 \\
\hline \multirow[t]{6}{*}{4} & Brown Thornbill & 1 & - & - & - & - & - & 3 & - & - & 2 & - & 3 & - & - & - & 1 & - \\
\hline & Green Rosella & - & - & - & - & - & - & - & 3 & 1 & - & - & - & - & - & - & & - \\
\hline & $\begin{array}{l}\text { Yellow } \\
\text { Wattlebird }\end{array}$ & - & - & - & - & - & - & - & - & - & - & - & - & - & - & - & 2 & - \\
\hline & $\begin{array}{l}\text { Yellow-throated } \\
\text { Honeyeater }\end{array}$ & 1 & - & - & - & - & - & - & - & - & - & - & - & - & - & - & - & - \\
\hline & Other & 1 & 1 & - & - & - & 1 & - & - & - & 2 & - & - & 2 & - & - & - & - \\
\hline & $\begin{array}{l}\text { Flowering } \\
\text { (\% receptive) }\end{array}$ & 0 & 0 & 1 & 1 & 5 & 10 & 25 & 80 & 45 & 80 & 70 & 70 & 75 & 50 & 0 & 0 & 0 \\
\hline \multirow[t]{3}{*}{5} & Brown Thornbill & - & - & - & - & - & - & - & - & - & 1 & - & - & - & - & - & - & - \\
\hline & Other & 3 & - & - & 1 & 1 & - & - & - & - & - & - & 1 & - & - & - & - & - \\
\hline & $\begin{array}{l}\text { Flowering } \\
\text { (\% receptive) }\end{array}$ & 0 & 0 & 0 & 0 & 0 & 0 & 1 & 2 & 20 & 30 & 30 & 30 & 40 & 60 & 5 & 5 & 5 \\
\hline \multicolumn{2}{|c|}{ Ambient temperature $\left({ }^{\circ} \mathrm{C}\right)$} & 10 & 10 & 7 & 12 & 11 & 12 & 10 & 10 & 14 & 10 & 9 & 12 & 13 & 18 & 15 & 12 & 12 \\
\hline \multicolumn{2}{|c|}{$\begin{array}{l}\text { Wind speed (terrestrial } \\
\text { Beaufort scale) }\end{array}$} & 1 & 5 & 3 & 5 & 5 & 4 & 5 & 5 & 4 & 4 & 4 & 3 & 2 & 4 & 4 & 4 & 4 \\
\hline \multicolumn{2}{|c|}{ Sunlight (S full, P partial) } & $S$ & $S$ & $S$ & $S$ & $S$ & $S$ & $S$ & $S$ & $S$ & $S$ & $S$ & $S$ & $\mathrm{P}$ & $\mathrm{P}$ & $\mathrm{P}$ & $S$ & $S$ \\
\hline \multicolumn{2}{|c|}{$\begin{array}{l}\text { Current moisture (D dry, } \\
\text { W wet) }\end{array}$} & $\mathrm{D}$ & $\mathrm{D}$ & $\mathrm{D}$ & $\mathrm{D}$ & $\mathrm{D}$ & $\mathrm{D}$ & $\mathrm{D}$ & W & $\mathrm{D}$ & $\mathrm{D}$ & $\mathrm{D}$ & $\mathrm{D}$ & $\mathrm{D}$ & $\mathrm{D}$ & $\mathrm{D}$ & $\mathrm{D}$ & $\mathrm{D}$ \\
\hline
\end{tabular}

